\title{
Trophic Indicators of Ecological Resilience in a Tidal Lagoon Estuary Following Wastewater Diversion and Earthquake Disturbance
}

\author{
John R. Zeldis ${ }^{1}$ (I) $\cdot$ Craig Depree $^{2} \cdot$ Catherine Gongol $^{3} \cdot$ Paul M. South $^{4} \cdot$ Andrew Marriner $^{5} \cdot$ David R. Schiel $^{6}$
}

Received: 17 October 2018 / Revised: 9 July 2019 / Accepted: 11 September 2019 / Published online: 24 October 2019

(C) The Author(s) 2019

\begin{abstract}
Estuary ecological resilience can be gauged by response of estuary trophic state to abatement of nutrient pollution. Changes in trophic indicators were studied in the Avon-Heathcote Estuary (AHE) in Christchurch, New Zealand, over 6 years, spanning diversion of city wastewater inputs to an offshore outfall in 2010, and to temporary enrichment caused by the 2011 Christchurch earthquake. It was hypothesised that the tidally well-flushed and sandy AHE would not harbour a 'legacy' of eutrophication and would rapidly gain improved ecological function following the diversion. AHE sediments were coarse $(156 \mu \mathrm{m}$ median grain size) with low organic matter (OM 1.2\%, N 0.03\%, C 0.3\%), which changed little either with diversion or earthquake. Upon diversion, median water column and porewater ammonium $(36,185 \mu \mathrm{mol})$ decreased by $87 \%$ and $57 \%$, respectively, benthic microalgae (269 mg chlorophyll- $a \mathrm{~m}^{-2}$ ) fell by $58 \%$, and enrichment-affiliated polychaetes $\left(3700-8000 \mathrm{~m}^{-2}\right.$ ) fell by $60-80 \%$ at sites with largest benthic microalgal reductions, all within $<1-2$ years. Oxygen and ammonium fluxes were usually oligotrophic and changed little upon diversion, except near the historic wastewater discharge site. Denitrification became more important for $\mathrm{N}$ loss, increasing from 5 to $29 \%$ of estuary N load. Responses to earthquake-driven enrichment were transient. Despite decades of heavy $\mathrm{N}$ loading and eutrophic growths of benthic microalgae and macroalgae, the AHE did not store a eutrophic legacy in its sediments. It reacted rapidly to improved water quality allowed by the outfall, showing that this common estuary type (sandy, well-flushed tidal lagoon) was resilient to eutrophication upon stressor removal.
\end{abstract}

Keywords Estuary $\cdot$ Eutrophication $\cdot$ Remediation $\cdot$ Resilience $\cdot$ Benthic $\cdot$ Management $\cdot$ New Zealand

\section{Introduction}

Improved understanding of estuary ecological resilience can be gained by examining how estuaries respond to abatement

Communicated by Cathleen Wigand

John R. Zeldis

John.Zeldis@niwa.co.nz

1 National Institute of Water and Atmospheric Research (NIWA), 10 Kyle St, Riccarton, Christchurch 8011, New Zealand

2 NIWA, PO Box 11115, Hillcrest, Hamilton 3216, New Zealand

3 NIWA, 10 Kyle St, Riccarton, Christchurch 8011, New Zealand

4 Cawthron Institute, 98 Halifax Street East, Nelson 7010, New Zealand

5 NIWA, 301 Evans Bay Parade, Hataitai, Wellington 6021, New Zealand

6 University of Canterbury, Private Bag 4800, Christchurch 8041, New Zealand of nutrient pollution upon removal of the stressor. Knowledge gained from such studies includes evaluating the cost-benefit of potentially costly pollution abatement efforts, and a deeper understanding of how estuary physical and ecological structure affect rates of recovery once the stressor is removed. Jones and Schmitz (2009) accumulated a global database describing terrestrial and aquatic ecosystems that have recovered from stress, with the finding that many systems recovered more rapidly than expected. They suggested that aquatic systems often showed shorter recovery times than terrestrial systems, which may be a consequence of shorter turnover times of species and nutrient pools in aquatic systems. Here, we provide evidence that this association with turnover may also apply to variation in recovery rates among estuary types, related to their physiography.

Borja et al. (2010) provided a meta-analysis of restoration trajectories of estuaries worldwide and concluded that while some systems took decades to show substantial recovery after nutrient pollution abatement, others recovered rapidly (in < 5 years). They described more rapidly recovering estuaries as 
high energy systems with coarse sediments and high organic matter turnover (low storage). These can be contrasted with systems with relatively slow rates of recovery including Odense Fjord, Denmark (Valdemarsen et al. 2014), Tolo Harbour, Hong Kong (Hu et al. 2001), Tampa Bay Florida (NRC 2000), and Kaneohe Bay, Hawaii (Smith et al. 1981) which sustained historical siltation from catchment runoff and sewage and had relatively slow response rates for several ecological indicators. Those systems harboured a 'legacy' of impact in the form of stored organic matter. In well-flushed Boston Harbour, however, significant steps toward recovery occurred after wastewater upgrades, with rapid reductions in nutrient concentration after load reductions, but somewhat slower (2-3 years) responses by primary producers, macrobenthos and DO levels related to lagged sediment organic matter consumption (Diaz et al. 2008; Taylor et al. 2011). Taken together, these studies indicated that resilience to eutrophication depends on estuary physiography, including the nature of load source, estuary morphology, hydrodynamics and basic bulk properties, such as sediment texture and organic matter content. However, as noted by Borja et al. (2010), there are few examples of long-term monitoring studies that combined biological elements together with physicochemical data from waters and sediments, which showed the recovery trajectories during remediation.

This study aimed to achieve that objective. It describes the recent history of the Avon-Heathcote Estuary (AHE) at Christchurch, New Zealand, as an example of estuary response to nutrient abatement and ecological resilience. This small $\left(7 \mathrm{~km}^{2}\right.$ ), shallow (mean depth 1.9 m HWS), mesotidal lagoon estuary received all of Christchurch's (present population 330,000) wastewater for over 100 years, until the commissioning of a \$NZ 80 M ocean outfall in March 2010 which diverted the wastewater offshore to the adjacent Pegasus Bay (Fig. 1). Prior to the diversion, the release of wastewater (ca. 170,000 $\mathrm{m}^{3}$ day $^{-1}$ in 2005) contributed ca. $88 \%$ and $97 \%$ of the AHE's ammonium $\left(\mathrm{NH}_{4}-\mathrm{N}\right)$ and dissolved reactive phosphorus (DRP) loads, at 5500 and $900 \mathrm{~kg} \mathrm{day}^{-1}$, respectively (Bolton-Ritchie and Main 2005). In contrast, most of its nitrate $\left(\mathrm{NO}_{3}-\mathrm{N}\right)$ load (ca. $94 \%$, $470 \mathrm{~kg} \mathrm{day}^{-1}$ ) came from its contributing rivers, the Avon and Heathcote Rivers (Burge 2007). A nutrient budget of total river and small drain loads compared to wastewater loads predicted that DIN loads to the AHE would reduce by $90 \%$ following the diversion (Burge 2007; Bolton-Ritchie 2015) showing the potential impact on water quality.

The changes afforded by the wastewater diversion presented an ideal opportunity to track ecological indicators of recovery and resilience resulting from this very strong perturbation to the trophic system of the AHE. However, unknown at study inception in 2006 was that a further perturbation was to occur in this estuary and its catchment: the powerful earthquake striking Christchurch on 22 February 2011 https://en.
wikipedia.org/wiki/2011_Christchurch_earthquake. The earthquake changed estuary inundation profile and ejected liquefacted subsurface sediment onto the estuary bed (Measures et al. 2011; Zeldis et al. 2011). It partially disabled Christchurch's wastewater infrastructure for several months, such that between 22 February and June 2011, an average of $21 \%$ of Christchurch's daily wastewater flow did not reach the new ( $\sim 1$ year old) ocean outfall but instead flowed directly to the estuary as untreated sewage, mainly via the Avon and Heathcote Rivers (Christchurch City Council unpublished data). This was gradually repaired until normal flows to the outfall were fully restored by late October 2011 . These temporary nutrient loadings provided further opportunities to study responses to eutrophic perturbations, along with the wastewater diversion in March 2010.

Prior to the diversion, median concentrations of total nitrogen $(\mathrm{TN})$ in the inner estuary were between 160 and $330 \mu \mathrm{mol} \mathrm{L}^{-1}$ (Bolton-Ritchie and Main 2005), indicating a hypertrophic system (Smith et al. 1999). These concentrations were maintained even though the AHE is well-flushed by the tide, with $64 \%$ of its high-tide volume occupied by its spring tidal prism. The AHE has widespread, shallow intertidal areas (66\% intertidal: Fig. 1), and eutrophication had been expressed as a change from submerged aquatic vascular vegetation (seagrass: Zostera muelleri) to high biomasses of nuisance macroalgae (Ulva spp. and Gracilaria spp.) (BoltonRitchie and Main 2005; Barr et al. 2012), as often seen in enriched shallow estuaries (Sutula et al. 2014). Benthic microalgae (BMA) were also very abundant in the AHE, forming thick, highly visible films, again like other eutrophic estuaries (MacIntyre et al. 1996; Tyler et al. 2003).

In a prelude to our study, Vopel et al. (2012) examined conditions in the AHE in 2007 and 2008, prior to the 2010 wastewater diversion. They found that AHE sediments were relatively coarse, consistent with low silt fractions previously found in AHE sediment surveys (Fig. 1), and had low \%mud, $\%$ organic matter $(\mathrm{OM}), \% \mathrm{C}$ and $\% \mathrm{~N}$. From these prediversion findings in the AHE, and considering other research summarized above, we hypothesised that the well-flushed AHE would not harbour a long-lived, post-diversion legacy of eutrophication driven from sediments and would recover ecological health relatively rapidly following the wastewater diversion.

\section{Methods}

To test our hypothesis, we studied the extent and rate of change of trophic indicators over a 6-year period centred on the March 2010 wastewater diversion. The indicators sampled were water column nutrients, sediment bulk properties (grain size, $\% \mathrm{OM}, \% \mathrm{~N}, \% \mathrm{C},-\delta_{15} \mathrm{~N}$ isotope and porosity), sediment porewater nutrients, BMA biomass, macrofaunal abundance, 
a

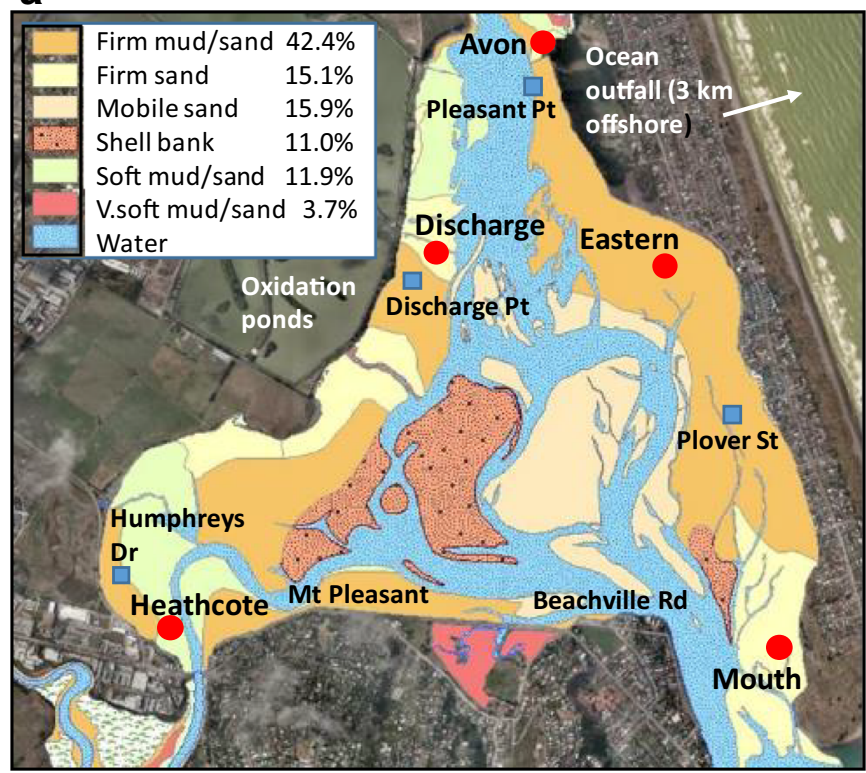

Fig. 1 a Avon-Heathcote Estuary (AHE) adjacent to Christchurch, New Zealand, showing the five survey sites (red circles: Discharge, Avon, Heathcote, Eastern, Mouth). Also shown are the Christchurch Wastewater Treatment Plant (CWTP) oxidation ponds and the ocean outfall location, sampling locations for water used in sediment incubations (Mt Pleasant and Beachville Rd) and locations used in

and sediment fluxes of oxygen, dissolved nutrients and denitrification. We used the same five sites originally sampled by Vopel et al. (2012) (Fig. 1): near the historic wastewater discharge point (Discharge), near the two river mouths (Avon and Heathcote), on the bar in the eastern estuary (Eastern) and near the estuary mouth (Mouth). Routine sampling was allocated to winter (July-September) and summer (November-February) each year.

\section{Water Column Nutrients}

Water quality data collected by the local regional council, Environment Canterbury (ECan), were extracted for locations nearest our five sampling sites. Methods of sample collection and analysis were described by Bolton-Ritchie (2015). Sampling was monthly, within $2 \mathrm{~h}$ of high tide. Data used were for $\mathrm{NH}_{4}-\mathrm{N}, \mathrm{NO}_{3}-\mathrm{N}$ and DRP.

\section{Sediment Properties and Porewater Nutrients}

At each site, sampling for sediment properties was done at three shore levels corresponding to low, mid and high neap tide levels, generally within $2 \mathrm{~h}$ of tidal emergence. The exception was the Heathcote site, which had no high-shore level because of the presence of a seawall inundated at high tide. At each site/shore level, two permanent GPS points $30 \mathrm{~m}$ apart were located parallel to the bathymetry. To avoid sediments which had been disturbed by previous samplings, a distinct b

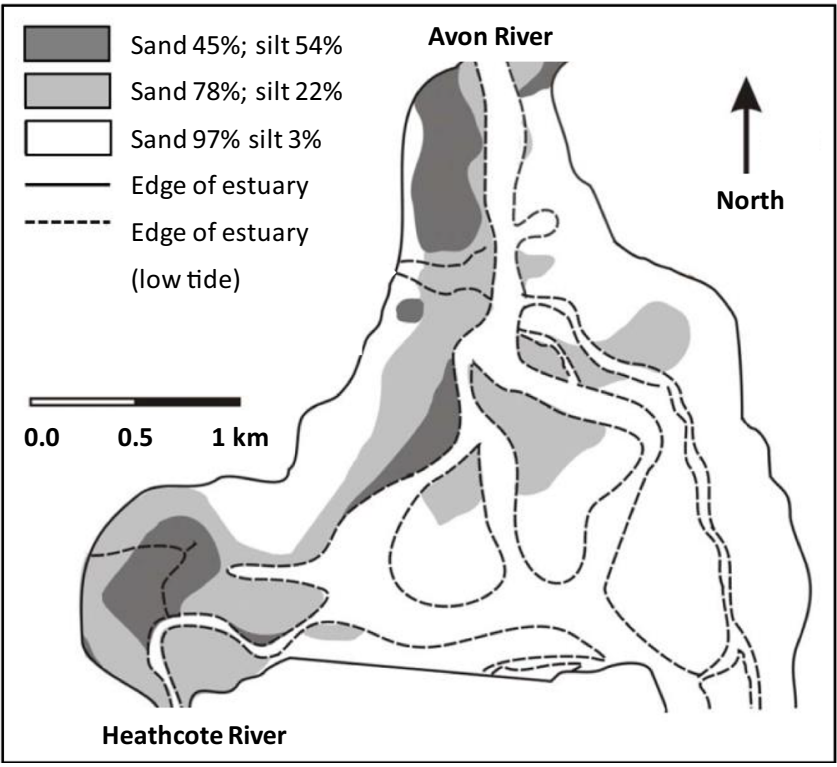

Bolton-Ritchie (2015) (blue squares). The colour coding shows the distributions and percentages of intertidal sediment types surveyed in 2002 by Robertson et al. (2002). b Proportions of sand and silt in AHE sediments, adapted from the 330-sample, 1981 survey of Rodrigo (1989) (adapted by Burge (2007))

location was randomly chosen between these GPS points at each sampling occasion. Following the February 2011 earthquake, when liquefaction mounds occurred at the sites, the mounds were avoided, and only undisturbed, nearby original estuary surface was sampled.

On each sampling date, three replicate cores were taken within $3 \mathrm{~m}$ of each other at each shore level. Cores were taken using cut-off $60 \mathrm{ml}(30 \mathrm{~mm}$ i.d.) plastic syringes pushed into the sediments, returned to the lab and frozen $\left(-20{ }^{\circ} \mathrm{C}\right)$. The surface $1 \mathrm{~cm}$ of one of the replicate cores (replicate 1) was sectioned off, homogenized and 1-3 g were set aside for isotope, $\% \mathrm{C}, \% \mathrm{~N}$ and particle size analyses (see below). The remaining sediment was dried $\left(60{ }^{\circ} \mathrm{C}, 24 \mathrm{~h}\right)$, then sampled for $\% \mathrm{OM}$ using $3 \mathrm{~g}$ sediment and weight loss after combustion at $400{ }^{\circ} \mathrm{C}$ for $6 \mathrm{~h}$. For particle size, small wet samples (< $1 \mathrm{~g}$, unless very sandy) were dispersed in washing solution (sodium hydrogen carbonate $(4 \mathrm{~g} / 20 \mathrm{~L}$ ) and sodium carbonate anhydrous $(1 \mathrm{~g} / 20 \mathrm{~L}))$, sonicated for $\sim 5 \mathrm{~s}$ and pre-filtered $(1.6 \mathrm{~mm})$ to remove particles that might block the $2 \mathrm{~mm}$ tubing in the laser sizer. Samples were run through a Beckman Coulter LS 13320 Laser Diffraction Particle Size Analyzer, achieving median obscuration $\sim 7 \%$. Results were processed through Gradistat version 8. Particle sizes were grouped into mud (coarse silt to clay) and sand (very coarse sand to very fine sand) categories. For $-\delta^{15} \mathrm{~N}$ stable isotope, $\% \mathrm{C}$ and $\% \mathrm{~N}$ analyses, sediment was finely ground with mortar and pestle, acidified $(0.1 \mathrm{~N}$ hydrochloric acid overnight, DI water rinsed and dried at $60^{\circ} \mathrm{C}$ overnight) and assayed on a Delta V Plus 
continuous flow, isotope ratio mass spectrometer linked to a Flash 2000 elemental analyser (Thermo-Fisher Scientific, Bremen, Germany) using a zeroblank autosampler (Costech Analytical, Valencia, CA, USA).

Averages of sediment bulk properties were taken across the low, mid and high shore levels to calculate their mean values at each of the five sites, on each date. To examine withinshore-level variation at each site, the sediment analyses were repeated at 5\% frequency on core replicates 2 and 3. This yielded mean CV's (sample SD/sample mean) of 3.5\% and $17.0 \%$ for the sand and mud fractions, respectively. Repeat analysis for $-\delta^{15} \mathrm{~N}$ stable isotope, $\% \mathrm{C}$ and $\% \mathrm{~N}$, yielded mean CV's of $8.6 \%$ for $-\delta^{15} \mathrm{~N}$ and $5.4 \%$ and $7.7 \%$ for $\% \mathrm{~N}$ and $\% \mathrm{C}$, respectively. The bulk properties analysis was augmented by a longer time series of \%OM and porosity sampling using sediments incubated for $\mathrm{O}_{2}$ and nutrient fluxes (see sediment incubation section, below). Porosity (void volume to total volume) was measured as proportion water times sediment density. Proportion water was calculated as the ratio of dry sediment weight $\left(60^{\circ} \mathrm{C}, 24 \mathrm{~h}\right)$, to saturated wet weight. Density was calculated by comparing water displacement to mass increase.

Sampling for sediment porewater nutrient concentrations was done at the five sites, at the low shore level. Triplicate porewater profiles were obtained using three cores taken within $4 \mathrm{~m}$ of each other on the $30 \mathrm{~m}$ transects. The cores used were clear acrylic tubes (300 mm long, $90 \mathrm{~mm}$ i.d.) drilled with a vertical 'bank' of 2.4-mm holes at 10-mm intervals down-core, which were covered using insulation tape prior to insertion into the sediment. The inserted cores were removed from the sediment and core bases attached. Low-tide water was carefully added to the core to immerse the sediment surface (using a 'bubble wrap' insert to avoid disturbing the surface). A knitting needle was used to pierce the tape covering the holes, and 5-cm-long porewater sippers (Rhizosphere CSS) were inserted horizontally at 5, 15,25 and $45 \mathrm{~mm}$ below the sediment surface. A 20-ml syringe was attached to the luer-loc fitting of the sipper and a vacuum applied until an approximately 2-3 $\mathrm{ml}$ sample volume was obtained. Porewater samples were stored chilled in the field and frozen $\left(-20{ }^{\circ} \mathrm{C}\right)$ within $6 \mathrm{~h}$ of sampling. Nutrient concentrations $\left(\mathrm{NH}_{4}{ }^{+}-\mathrm{N}, \mathrm{NO}_{3}-\mathrm{N}\right.$ and DRP) were determined using flowinjection analysis for seawater (Lachat 2010).

\section{Benthic Microalgal Abundance}

Sampling for BMA abundance was done at the three shore levels of the five sites, using pigment analyses of surface sediments. Five randomly chosen positions were located within $5 \mathrm{~m}$ of each other at the same transect location as for bulk properties sampling. Surface sediment was collected using a $48 \mathrm{~mm}$ i.d. 'minicore' (a titanium disk with 2-mm-deep returns on both sides (Ford and Honeywill 2002) pressed into the surface sediment and frozen with liquid nitrogen. This extracted sediment was shaved off to yield a frozen 2-mmthick disk of sediment which was wrapped in foil, transported in liquid nitrogen to the lab and stored at $-80{ }^{\circ} \mathrm{C}$. Freezedried, weighed subsamples (10 $\mathrm{mm}$ diameter punch) of the disks were extracted by sonication (15 pulses) in $5 \mathrm{ml}$ of $90 \%$ acetone, followed by addition of a further $5 \mathrm{ml}$ of acetone and refrigeration $\left(4{ }^{\circ} \mathrm{C}, 4 \mathrm{~h}\right)$. Centrifuged extract $(3000 \mathrm{rpm}$, $10 \mathrm{~min}$ ) was assayed by spectrophotometer for chlorophyll- $a$ (chl-a) calculated using equations of Jeffrey and Humphrey (1975).

\section{Sediment Oxygen, Nutrient and Denitrification Fluxes}

Laboratory sediment $\mathrm{O}_{2}$, nutrient and dentrification flux incubations were made using sediment cores collected from the low shore level. On each occasion, sediment collections and incubations were made sequentially over five successive days in the order: Eastern, Mouth, Avon, Heathcote, Discharge. At each site, six replicate sediment cores were collected using 300-mm-long, 90-mm i.d acrylic cores, within $4 \mathrm{~m}$ of each other on the $30 \mathrm{~m}$ transects. The cores were pushed into the sediment until filled to $\sim 200 \mathrm{~mm}$ sediment depth, removed and fitted with bases and lids, and transported in a cool box to the laboratory within $1 \mathrm{~h}$ of collecting.

In the laboratory, the cores were incubated in recirculating seawater with salinity and nutrient status representative of the estuary regions from which the cores were collected: for Eastern and Mouth, water was collected at Beachville Rd in the outer estuary (Fig. 1) and for Avon, Heathcote and Discharge, water was collected at Mt. Pleasant in the inner estuary (both at high tide). The cores were immersed in $38 \times 38 \mathrm{~cm}$ white plastic containers filled to a depth of $48 \mathrm{~cm}$ and fed with recirculating, temperature-controlled water at $111 \mathrm{~min}^{-1}$. Water was filtered and sterilized using a $1-\mu \mathrm{m}$-pore cartridge pool filter and ultraviolet light (Germicida). The cores were left to equilibrate uncovered overnight in darkness.

At $\mathrm{T}_{0}(0800 \mathrm{~h})$, five of the cores were closed with lids fitted with motorized magnetic stirrers $(60 \mathrm{rpm})$ that stirred the water column without resuspending the sediment. A sixth core containing no sediment was filled with incubation water and closed, as a blank. Triplicate incubation water samples were taken for nutrients $\left(\mathrm{GF} / \mathrm{F}\right.$ filtered, frozen at $-20{ }^{\circ} \mathrm{C}$ for $\mathrm{NH}_{4}$ $\mathrm{N}, \mathrm{NO}_{3}-\mathrm{N}, \mathrm{DRP}$ assayed as for porewater. Water samples for denitrification measurements (see below) were also taken. Temperature and dissolved oxygen (DO) concentration were measured with a Unisense OX50 Clark-type oxygen microsensor. Dark incubation times ranged between 1.5 and $4 \mathrm{~h}$, regulated to keep DO within $20 \%$ of the original value measured via a microsensor inserted through a sampling port. At completion of the dark incubation $\left(\mathrm{T}_{1}\right)$, the cores were opened and sampled for nutrients and denitrification. The opened 
cores were then equilibrated under light conditions for $2 \mathrm{~h}$ in the recirculating bath. The lights (400 W Arcstream, ARC400/ T/H/742, Hungary 0405) supplied photosynthetically active radiation, Ed(PAR) of $670 \pm 30 \mu \mathrm{mol}$ quanta $\mathrm{m}^{-2} \mathrm{~s}^{-1}$ (mean $\pm \mathrm{SD}$ ) measured with a plane underwater quantum sensor (LI192SA, LI-COR Environmental) at the surface of the sediments, which decreased to $374 \pm 19 \mu \mathrm{mol}$ quanta $\mathrm{m}^{-2} \mathrm{~s}^{-1}$ when the cores were sealed. The closed cores were incubated 2-4 h, keeping DO within $20 \%$ of the original value. Sampling in the light $\left(\mathrm{T}_{0}\right.$ and $\left.\mathrm{T}_{1}\right)$ for DO, nutrients and denitrification was identical to the dark incubations. For dark and light incubations, fluxes of nutrients and oxygen were calculated as the difference between the final and initial concentrations in the water column of the cores prorated for the volume of water overlying the core, the sediment area of the core and incubation time, to calculate net areal fluxes.

Net denitrification was measured in the dark and light incubations as excess dinitrogen $\left(\mathrm{N}_{2}\right)$ evolved during incubations, relative to changes of $\mathrm{N}_{2}$ and argon (Ar) in the blank cores (Kana et al. 1994). Triplicate samples were taken in 10$\mathrm{ml}$ gas-tight glass vials (exetainers) filled to overflowing, killed with $10 \mu \mathrm{l}$ saturated mercuric chloride and stored submerged, below in situ temperature, until analysis. Dissolved gas samples were analysed for $\mathrm{N}_{2}, \mathrm{O}_{2}$ and Ar with a quadrupole membrane inlet mass spectrometer (MIMS). Net denitrification was calculated with Ar normalisation using blank Ar and $\mathrm{N}_{2}$ values as:

\section{Excess $\mathrm{N}_{2 \text { final }}=\left(\mathrm{N}_{2}\right.$ core $\left./ \mathrm{Ar}_{\text {core }} \times \mathrm{Ar}_{\text {blank }}\right)-\mathrm{N}_{2 \text { blank }}$}

where $\mathrm{N}_{2 \text { blank }}$ is $\mathrm{N}_{2}$ concentration at the end of the incubation in the absence of sediment, and the bracketed term is $\mathrm{N}_{2}$ at the end of incubation in the presence of sediment, corrected by the change in $\mathrm{Ar}$ in the core, relative to $\mathrm{Ar}$ in the absence of sediment. Excess $\mathrm{N}_{2}$ was then prorated for the volume of water overlying the core, the sediment area of the core and incubation time, to calculate areal net denitrification ( $\mu \mathrm{mol} \mathrm{N} \mathrm{m}^{-2} \mathrm{~h}^{-1}$ ).

In practice, we found that while the dark incubations yielded realistic values of net denitrification, the light incubations yielded unrealistically high and very variable values of net $\mathrm{N}$ fixation in most cases. We attribute this to the presence of active BMA in the cores, which produced considerable $\mathrm{O}_{2}$ in the light (often supersaturated: see $\mathrm{O}_{2}$ flux results). The $\mathrm{O}_{2}$ was sometimes visible as tiny bubbles on the sediment core surfaces. Oxygen microbubbles have been observed previously to bias the gas solubility dynamics involved in the $\mathrm{N}_{2} / \mathrm{Ar}$ method, via differential gas stripping between $\mathrm{N}_{2}$ and $\mathrm{Ar}$ (Kana et al. 1994; Eyre et al. 2002; Kana and Weiss 2004), an effect also seen by Cornwell et al. (2014). Further evidence that this was occurring was seen in our light incubations as a much greater dependence of $\left[\mathrm{N}_{2}\right]$ on $\left[\mathrm{O}_{2}\right]$ than would be expected (e.g. in our May 2008 incubation we saw changes of
$0.29 \mu \mathrm{mol} \mathrm{N}_{2}$ per $\mu \mathrm{mol} \mathrm{O}_{2}$, compared to that expected in conditions of undersaturated $\mathrm{O}_{2}$ (e.g. $\sim 0.05 \mu$ mol $\mathrm{N}_{2}$ per $\mu \mathrm{mol} \mathrm{O}_{2}$ in Kana and Weiss (2004): their Fig. 2). For these reasons, in this study, we consider only our dark denitrification determinations to be valid.

Macrofauna were sieved $(500 \mu \mathrm{m})$ from the five experimental cores upon completion of the incubations, preserved in $10 \%$ ethanol, identified to lowest possible taxon and counted. The sixth sediment-filled core was analysed for sediment $\% \mathrm{OM}$ and porosity (as described above) in the upper $60 \mathrm{~mm}$ of sediment.

\section{Statistical Analysis}

Significance of differences between treatments was tested using parametric ANOVA for cases where variances were shown to be homoscedastic (Cochran's $C$ ). In several cases variances were significantly heteroscedastic and resistant to transformation (logarithmic or double square-root). Nonparametric testing (Kruskal-Wallis or Mann-Whitney $U$ ) was used in these cases.

\section{Results}

\section{Water Column Nutrients}

Time series of ECan water quality monitoring showed highest $\mathrm{NH}_{4}-\mathrm{N}$ and DRP values at inner estuary sites (Discharge, Avon and Heathcote), and lower values at outer estuary sites (Eastern and Mouth) (Table 1, Fig. 2). Values of $\mathrm{NO}_{3}-\mathrm{N}$ were highest at the river mouth sites (Avon and Heathcote). Prewastewater diversion, concentrations of $\mathrm{NH}_{4}-\mathrm{N}$ were high and variable but had large decreases (52-88\%) within a few months following the diversion. Post-earthquake (after February 2011), $\mathrm{NH}_{4}-\mathrm{N}$ increased at river sites (Avon and especially Heathcote: Fig. 2), due to sewage overflows into the rivers. DRP showed similar trajectories post-diversion and post-earthquake. Reductions in $\mathrm{NO}_{3}-\mathrm{N}$ following wastewater diversion were less pronounced than for $\mathrm{NH}_{4}-\mathrm{N}$ because the major source of $\mathrm{NO}_{3}-\mathrm{N}$ was not the wastewater discharge, but the Avon and Heathcote Rivers, which were not remediated. Consequently, the post-diversion reductions in DIN (sum of $\mathrm{NH}_{4}-\mathrm{N}$ and $\mathrm{NO}_{3}-\mathrm{N}$ ) were intermediate between those of $\mathrm{NH}_{4}$ $\mathrm{N}$ and $\mathrm{NO}_{3}-\mathrm{N}$ (Table 1), averaging 57\% across the sites.

\section{Sediment Bulk Properties and Porewater Nutrients}

Significant differences were found between sites for all bulk properties (Table 2; Fig. 3) except $-\delta^{15}$ N. Few significant differences were found between the pre- and post-diversion periods, except for $\% \mathrm{~N}$ and $-\delta^{15} \mathrm{~N}$, which showed significant interactions of factor Site and factor Pre/post. The significant 

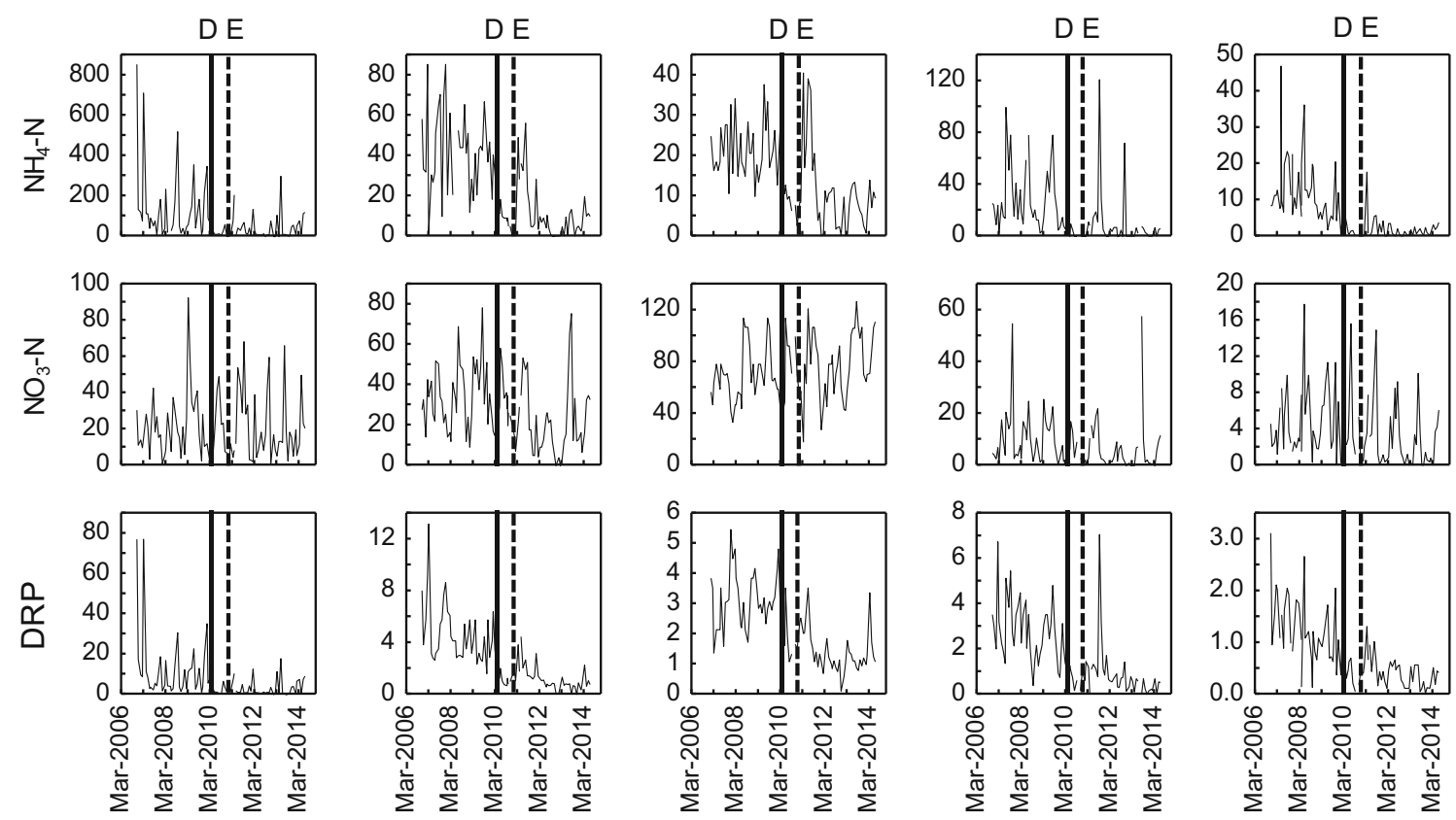

\section{Discharge}

Avon

Heathcote

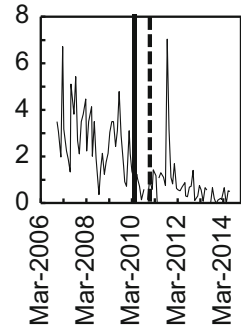

Eastern

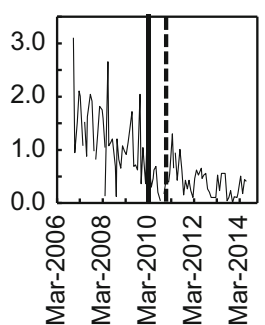

Mouth
Fig. 2 Variation of $\mathrm{NH}_{4}-\mathrm{N}, \mathrm{NO}_{3}-\mathrm{N}$ and DRP ( $\mu$ mol: monthly values) sampled at high tide at ECan water quality monitoring locations near the five sites, 2006-2014. Times of March 2010 wastewater diversion
(D) and February 2011 earthquake (E) are shown. Note the large difference in scale for $\mathrm{NH}_{4}-\mathrm{N}$ and DRP at site Discharge

flux incubation experiments (Fig. 4; Table 3), collected during 3 years before, to 3 years following the diversion. For \%OM, there were no effects of factor 'Pre/post diversion' or 'Site*Pre/post' interactions at any site (2-way ANOVA: not shown). There were 'Site' effects $(p<0.001)$, with the same spatial gradients of $\% \mathrm{OM}$ as the surveys of Fig. 3 (higher $\% \mathrm{OM}$ at inner than outer estuary sites). The highest \%OM was recorded at Heathcote, in the first sampling after the earthquake (July 2011: Fig. 4). Porosity showed no effects of 'Site', 'Pre/post' or their interaction and was uniformly low (Table 3), consistent with the low proportions of fines and sandy nature of the sediments (Fig. 1).

Porewater nutrient concentrations in the upper $45 \mathrm{~mm}$ of sediment decreased significantly at most sites following the

Table 1 Water column and porewater nutrient concentrations ( $\mu \mathrm{mol}$, medians) at the five study sites in AHE. Shown are pre-/post-wastewater diversion concentrations (in bold), and probabilities ( $p$ : Mann-Whitney

$U$ ) that the pre- and post-diversion concentrations were from the same populations $(p \leq 0.050$ italicized)

\begin{tabular}{|c|c|c|c|c|c|c|c|}
\hline \multirow[t]{2}{*}{ Site } & \multicolumn{4}{|c|}{ Water column nutrients pre/post } & \multicolumn{3}{|c|}{ Porewater nutrients pre/post } \\
\hline & $\mathrm{NH}_{4}-\mathrm{N}$ & $\mathrm{NO}_{3}-\mathrm{N}$ & DIN & DRP & $\mathrm{NH}_{4}-\mathrm{N}$ & $\mathrm{NO}_{3}-\mathrm{N}$ & DRP \\
\hline Discharge & $\mathbf{8 6} / \mathbf{1 2} p<0.001$ & $\mathbf{1 7 / 1 6} p=0.610$ & $\mathbf{1 0 3 / 2 8} p<0.001$ & 7.0/1.4 $p<0.001$ & $\mathbf{3 4 0 / 1 2 4} p<0.001$ & $\mathbf{5} / \mathbf{3} p=0.040$ & $142 / 29 p<0.001$ \\
\hline Avon & $\mathbf{4 3 / 8} p<0.001$ & $\mathbf{3 3} / \mathbf{2 1} p=0.003$ & $76 / 29 p<0.001$ & 4.2/1.0 $p<0.001$ & $197 / 87 p=0.002$ & $\mathbf{4 5 / 5} p=0.002$ & $\mathbf{9 5 / 2 6} p=0.004$ \\
\hline Heathcote & $\mathbf{2 0 / 1 0} p<0.001$ & $66 / 79 p=0.070$ & $\mathbf{8 6} / \mathbf{8 8} p=0.620$ & 3.1/1.3 $p<0.001$ & 175/111 $p=0.030$ & $\mathbf{3 4 / 8} p=0.006$ & $\mathbf{1 2 0 / 5 1} p=0.024$ \\
\hline Eastern & $\mathbf{2 0 / 3} p<0.001$ & $\mathbf{8} / \mathbf{3} p=0.003$ & $28 / 6 p<0.001$ & 2.7/0.7p $<0.001$ & $\mathbf{1 0 2} / \mathbf{6 3} p=0.117$ & $\mathbf{9} / \mathbf{3} p=0.022$ & $\mathbf{1 0 / 9} p=0.246$ \\
\hline Mouth & $\mathbf{9 / 1} p<0.001$ & $\mathbf{3} / \mathbf{2} p=0.010$ & $\mathbf{1 2 / 3} p<0.001$ & 1.1/0.5 $p<0.001$ & 112/10 $p<0.001$ & $\mathbf{2 4 / 8} p=0.030$ & $\mathbf{1 0} / \mathbf{1} p<0.001$ \\
\hline
\end{tabular}


Table 2 Variation in sediment bulk properties in AHE through time at four study sites. Shown are probabilities (two-way ANOVA) that levels of each factor were from the same populations ( $p \leq 0.050$ italicized). Site Eastern was excluded because it was not sampled in the pre-diversion period

\begin{tabular}{llllll}
\hline Factor & Grain size & $\% \mathrm{Mud}$ & $\% \mathrm{OM}$ & $\% \mathrm{~N}$ & $\% \mathrm{C}$ \\
\hline Site & 0.003 & $<0.001$ & 0.004 & $<0.001$ & $<0.001$ \\
Pre/post diversion & 0.969 & 0.618 & 0.968 & 0.265 & 0.077 \\
Site*Pre/post diversion & 0.396 & 0.460 & 0.459 & 0.019 & 0.425 \\
\hline
\end{tabular}

wastewater diversion (Table 1, Fig. 5) with $\mathrm{NH}_{4}-\mathrm{N}, \mathrm{NO}_{3}-\mathrm{N}$ and DRP decreasing by means of 57,62 and $61 \%$, respectively across the sites. Porewater DIN was dominated by $\mathrm{NH}_{4}-\mathrm{N}$.

\section{Benthic Microalgal and Macrofaunal Abundance}

Pre-diversion BMA biomass was high and variable, particularly at Discharge and Eastern sites (Fig. 6). After the diversion, there were significant falls in BMA biomass at 11 of the 14 site/shore-level combinations (Table 4), including very large reductions at Discharge and Eastern, to lower and more uniform levels across the sites (Fig. 6). Changes in BMA at the Mouth site upon diversion were less marked, reflecting lower water column and porewater nutrient conditions near the estuary entrance (Table 1). At the Heathcote low-shore site, a spike of BMA abundance occurred in July 2011, the first sampling after the February 2011 earthquake (Fig. 6). This coincided with large increases in water column $\mathrm{NH}_{4}-\mathrm{N}$ arising from raw sewage overflows into rivers (Fig. 2). This BMA maximum had gone by the next sampling (February 2012), after the overflows were remediated and water quality had improved. Excluding the July 2011 sample from the BMA analysis made little difference in post-diversion BMA median values at Heathcote (reduced from 111 to $105 \mathrm{mg}$ chl- $a \mathrm{~m}^{-2}$; $p=0.055$ pre- to post diversion).

A full analysis of the macrofaunal dataset derived from the core incubations was outside the scope of this study: here, we focus on abundant sedentary deposit-feeding polychaete taxa as indicators of eutrophication change (Cardoso et al. 2007). These taxa were most abundant pre-diversion at sites Discharge and Eastern (Fig. 7), where Capitellidae and Aonides trifida, respectively, contributed 80-92\% of all sedentary deposit-feeding polychaetes. Median densities $\left(\mathrm{m}^{-2}\right)$ of the capitellid assemblage at Discharge fell from $\sim 3700$ to $\sim$ 800 within 1 year $(p=0.005)$ pre- to post-diversion and the A. trifida assemblage at Eastern fell from $\sim 8000$ to $\sim 3200$ within 2 years $(p=0.012)$. These accompanied large reductions in BMA at both sites (Fig. 6; Table 4).

\section{Sediment Oxygen, Nutrient and Denitrification Fluxes}

Sediment $\mathrm{O}_{2}$ fluxes in darkness (dark sediment $\mathrm{O}_{2}$ consumption: SOC) were greatest at Discharge (Table 5, Fig. 8), intermediate at Avon, Heathcote and Eastern, and least at Mouth, following the \%OM trend among those sites (Figs. 3 and 4; Table 3). Dark SOC decreased by $\sim 1000 \mu \mathrm{mol} \mathrm{m}{ }^{-2} \mathrm{~h}^{-1}$, preto post-diversion at site Discharge and had a relatively small decrease at Mouth. There were no significant changes in SOC at other sites, pre- to post-diversion. Sediment $\mathrm{O}_{2}$ fluxes in light (net primary production (NPP)) were significantly greater than in dark at all 5 sites (Fig. 8), both pre- and postdiversion $(p<0.001$ for all 10 site-by-pre/post combinations: Mann-Whitney $U$, not shown). This indicated a uniform response to BMA primary production. NPP at Discharge site was high $\left(\sim 2400 \mu \mathrm{mol} \mathrm{m}{ }^{-2} \mathrm{~h}^{-1}\right)$ pre-diversion (Table 5) when BMA biomass there was high (Table 4, Fig. 6) but it fell to < $0 \mu \mathrm{mol} \mathrm{m}{ }^{-2} \mathrm{~h}^{-1}$ post-diversion as BMA decreased. The Discharge site thus became net-heterotrophic and much closer to the other sites in terms of trophic state. Smaller (but significant) NPP decrease occurred at the Mouth site, post-diversion. NPP increased at the Heathcote site post-diversion (Table 5: marginally non-significant at Avon), including a sharp, temporary increase in July 2011 (Fig. 8). This was associated with the post-earthquake sewage overflows into their respective rivers and temporarily increased $\mathrm{NH}_{4}-\mathrm{N}$ (Fig. 2) and BMA (Fig. 6). Exclusion of the July 2011 sample from the NPP analysis at Heathcote (not shown) resulted in no significant change in NPP $(p=0.293)$ pre- to post-diversion.

$\mathrm{NH}_{4}$-N fluxes (Table 5, Fig. 8) were largest at site Discharge, less at Avon, Heathcote and Eastern, and close to zero at Mouth. Dark $\mathrm{NH}_{4}-\mathrm{N}$ fluxes showed little change across the sites between pre- and post-diversion, although the larger changes at Discharge and Heathcote were only marginally rejected ( $p=$ 0.076: Table 5). For Discharge, the post-diversion values may have been kept high by the first two values immediately following the earthquake (Fig. 8). At all sites, pre- and post-diversion, fluxes of $\mathrm{NH}_{4}-\mathrm{N}$ from the sediment were reduced under light conditions (Fig. 8, Table 5): significant for 8 of the 10 , site $\times$ pre/post combinations and only marginally rejected at Eastern/pre $(p=0.068)$. This was likely caused by $\mathrm{NH}_{4}-\mathrm{N}$ uptake by BMA, as also indicated by the strong response of NPP to light (above). This BMA/light effect was greatest at the most eutrophic site, Discharge, where gross $\mathrm{NH}_{4}-\mathrm{N}$ flux (i.e. absolute difference of light and dark $\mathrm{NH}_{4}-\mathrm{N}$ fluxes: Table 5), fell by about $350 \mu \mathrm{mol} \mathrm{m} \mathrm{m}^{-2} \mathrm{~h}^{-1}$ post-diversion, and light and dark $\mathrm{NH}_{4}-\mathrm{N}$ fluxes converged (Fig. 8). Smaller but significant reductions also occurred at Avon and Heathcote sites and were only marginally rejected at the Mouth site. 

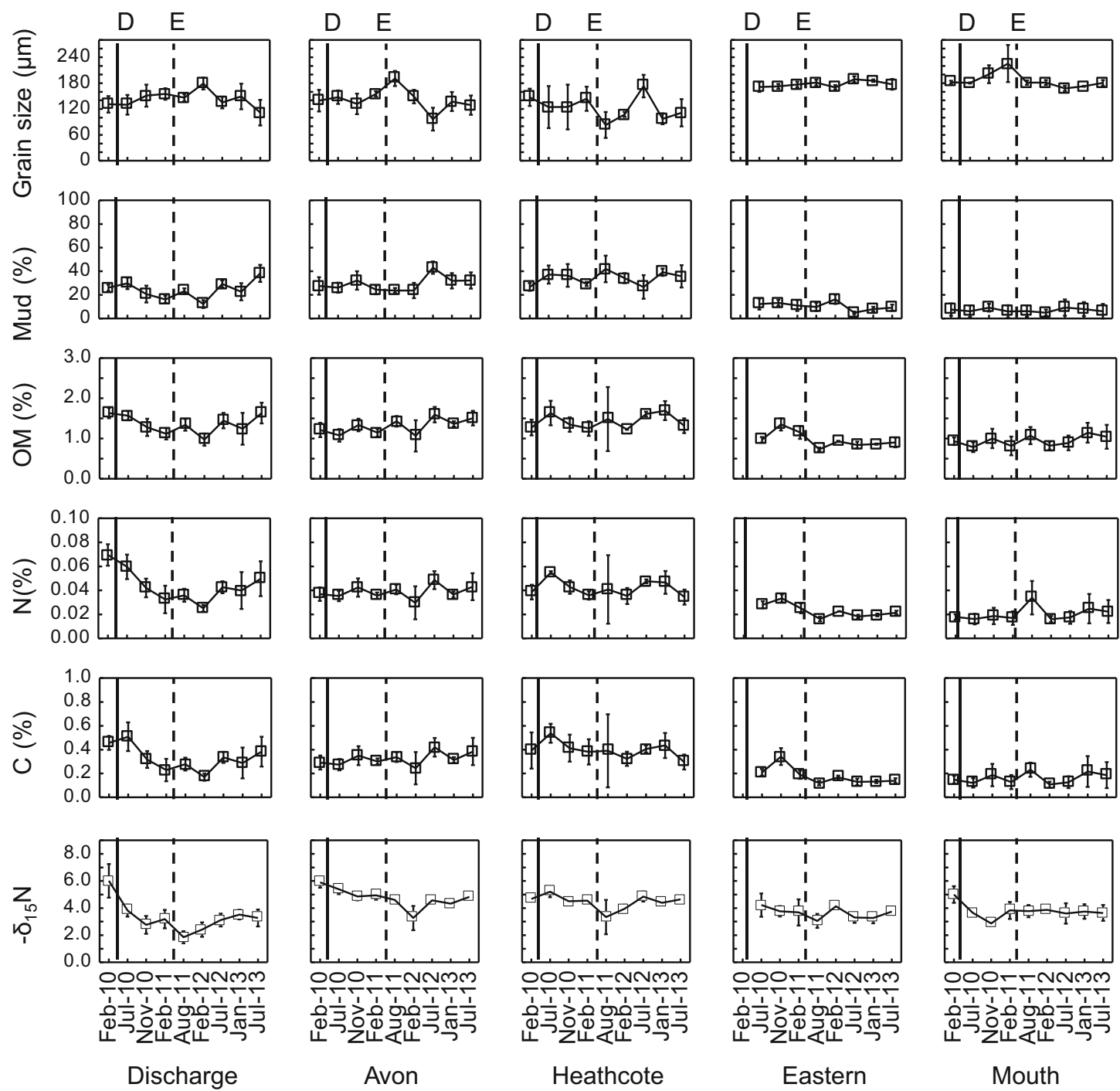

Fig. 3 Sediment bulk properties at the five sites (means and 1 SE), 2010-2013. Times of March 2010 wastewater diversion (D) and February 2011 earthquake (E) are shown. There were no pre-diversion data at Eastern

Fluxes of $\mathrm{NO}_{3}-\mathrm{N}$ were usually smaller than those of $\mathrm{NH}_{4}-\mathrm{N}$ (Fig. 8). Eight of the 10 site x pre/post combinations were net $\mathrm{NO}_{3}-\mathrm{N}$ sinks (Table 5), indicating active denitrification. Dark and light $\mathrm{NO}_{3}-\mathrm{N}$ fluxes tended to track each other more closely than dark and light $\mathrm{NH}_{4}-\mathrm{N}$

Table 3 Sediment bulk properties (means) at the five study sites in AHE, 2010-2013. Results of post hoc tests (Newman-Keuls) are shown with different letters indicating significantly different values $(p<0.050)$

\begin{tabular}{lllllllll}
\hline Site & Grain size $(\mu \mathrm{m})$ & $\%$ Mud & $\% \mathrm{OM}$ & $\% \mathrm{~N}$ & $\% \mathrm{C}$ & $-\delta^{15} \mathrm{~N}$ & $\%$ OM (incub.) & Porosity (incub.) \\
\hline Discharge & $146 \mathrm{a}$ & $23 \mathrm{a}$ & $1.37 \mathrm{a}$ & $0.04 \mathrm{a}$ & $0.33 \mathrm{a}$ & $3.33 \mathrm{a}$ & $1.40 \mathrm{a}$ & $0.40 \mathrm{a}$ \\
Avon & $143 \mathrm{a}$ & $29 \mathrm{~b}$ & $1.30 \mathrm{a}$ & $0.04 \mathrm{a}$ & $0.32 \mathrm{a}$ & $4.75 \mathrm{~b}$ & $1.10 \mathrm{a}$ & $0.37 \mathrm{a}$ \\
Heathcote & $126 \mathrm{a}$ & $33 \mathrm{~b}$ & $1.43 \mathrm{a}$ & $0.04 \mathrm{a}$ & $0.40 \mathrm{a}$ & $4.46 \mathrm{~b}$ & $1.56 \mathrm{a}, \mathrm{b}$ & $0.38 \mathrm{a}$ \\
Eastern & $178 \mathrm{~b}$ & $11 \mathrm{c}$ & $0.97 \mathrm{~b}$ & $0.02 \mathrm{~b}$ & $0.18 \mathrm{~b}$ & $3.65 \mathrm{a}$ & $1.14 \mathrm{a}, \mathrm{c}$ & $0.38 \mathrm{a}$ \\
Mouth & $187 \mathrm{~b}$ & $7 \mathrm{c}$ & $0.95 \mathrm{~b}$ & $0.02 \mathrm{~b}$ & $0.16 \mathrm{~b}$ & $3.78 \mathrm{a}$ & $0.73 \mathrm{~d}$ & $0.41 \mathrm{a}$ \\
\hline
\end{tabular}

fluxes (Fig. 8), with 7 of its 10 , site $\times$ pre/post combinations not significantly different between light and dark (not shown).

All sediments were sources of DRP pre- and post-diversion, in both light and dark conditions (Table 5, Fig. 8). Site

between sites. The final two columns are \%OM and porosity derived from oxygen and nutrient flux incubations 


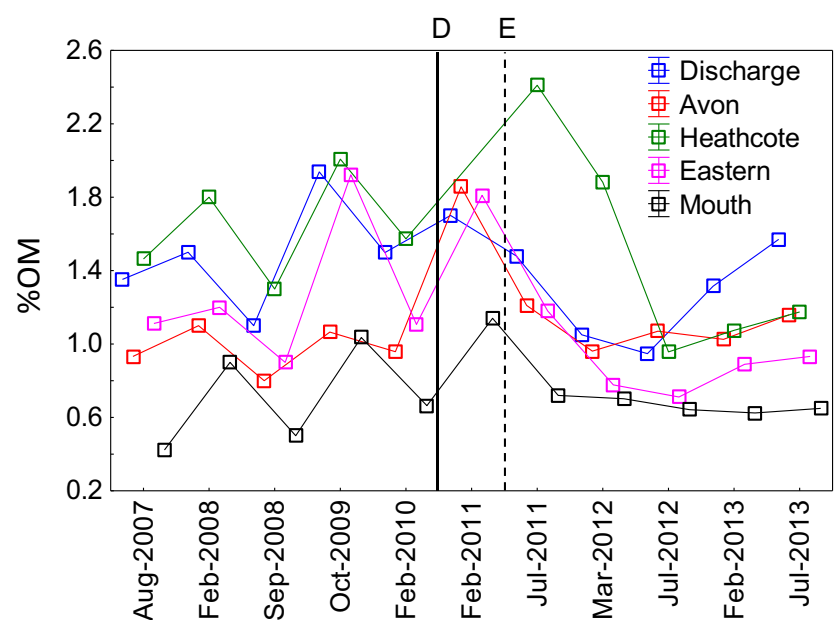

Fig. 4 Sediment \%OM over the upper $60 \mathrm{~mm}$ of sediment in cores used for flux incubations at the five sites, 2007-2013 ( $n=1$ for each site on each date). Times of March 2010 wastewater diversion (D) and February 2011 earthquake (E) are shown

Discharge showed large DRP fluxes before the diversion which decreased greatly post-diversion, a pattern like its porewater DRP changes (Table 1; Fig. 5). The other sites showed much lower pre-diversion DRP fluxes and mixtures of increased and decreased fluxes between pre- and postdiversion periods. There were no significant dark/light effects on the magnitudes of DRP fluxes except at Discharge, where light effluxes were less than dark, both pre- and post-diversion (Fig. 8).

Denitrification was greatest at Discharge, intermediate at Avon, Heathcote and Eastern and lowest at Mouth
(Table 5, Fig. 8), following the spatial patterns of DIN concentration in the water column and porewater (Table 1). Denitrification decreased significantly at Discharge, Avon and Mouth sites pre- to post-diversion. There were immediate post-earthquake denitrification peaks at Discharge and Heathcote, but from March 2012 onward, all sites had similar, relatively low denitrification $\left(\sim 50 \mu \mathrm{mol} \mathrm{N} \mathrm{N}_{2} \mathrm{~m}^{-2} \mathrm{~h}^{-1}\right.$ : Fig. 8$)$.

\section{Discussion}

The AHE ecosystem received major perturbations in 2010 and 2011, which enabled study of its responses to changes in eutrophication pressure. The first was the March 2010 diversion of the Christchurch wastewater stream out of the estuary to the ocean outfall. The second arose from breakdowns in the city's wastewater reticulation system and raw sewage flows into the estuary caused by the February 2011 earthquake. Here, we discuss AHE water column and sediment ecological indicators in terms of their rates of change in response to the diversion and earthquake, relative to typical estuarine values in the literature. The findings are used to describe the ecological resilience of this estuary and how this informs the question of ecological resilience of estuaries generally. We conclude by discussing how the results are applicable in the coastal management sphere.
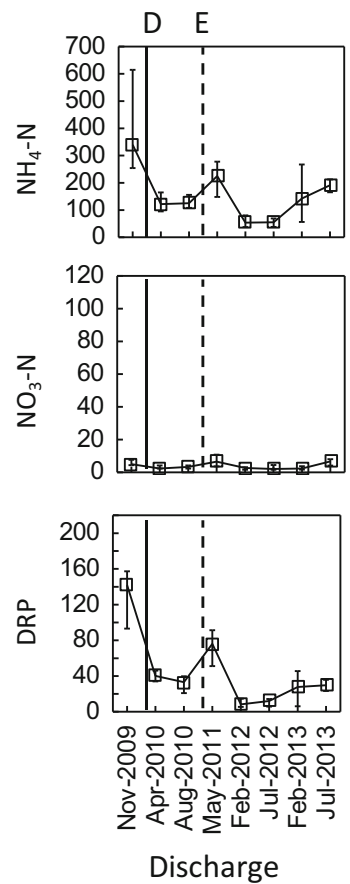
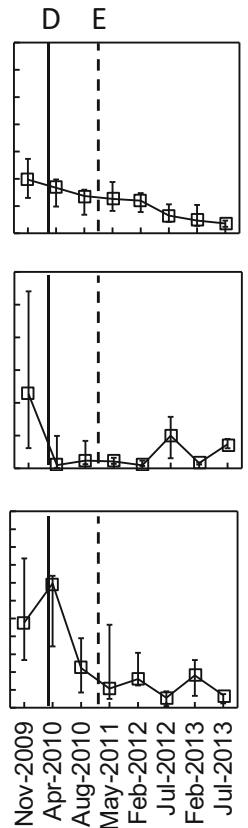

Avon
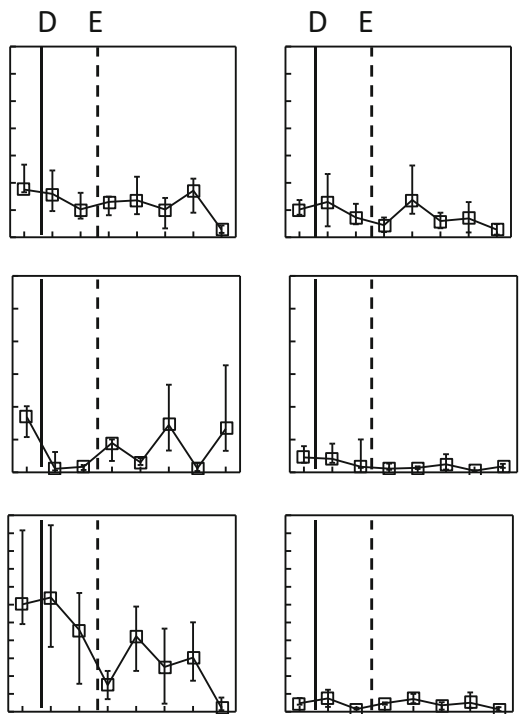

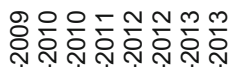

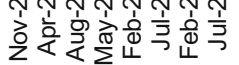

Eastern
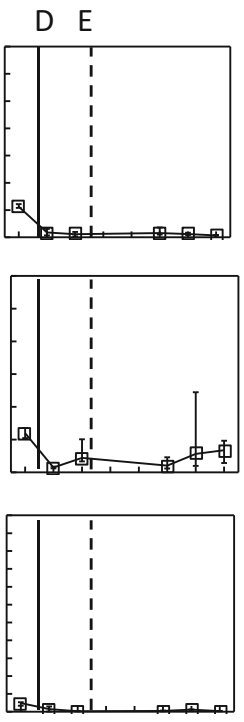

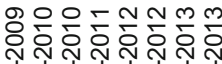

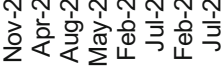

Mouth

Fig. 5 Porewater nutrient concentrations ( $\mu$ mol: medians and quartiles) over the upper $45 \mathrm{~mm}$ of sediment at the five sites, 2009-2013. Times of March 2010 wastewater diversion (D) and February 2011 earthquake (E) are shown 

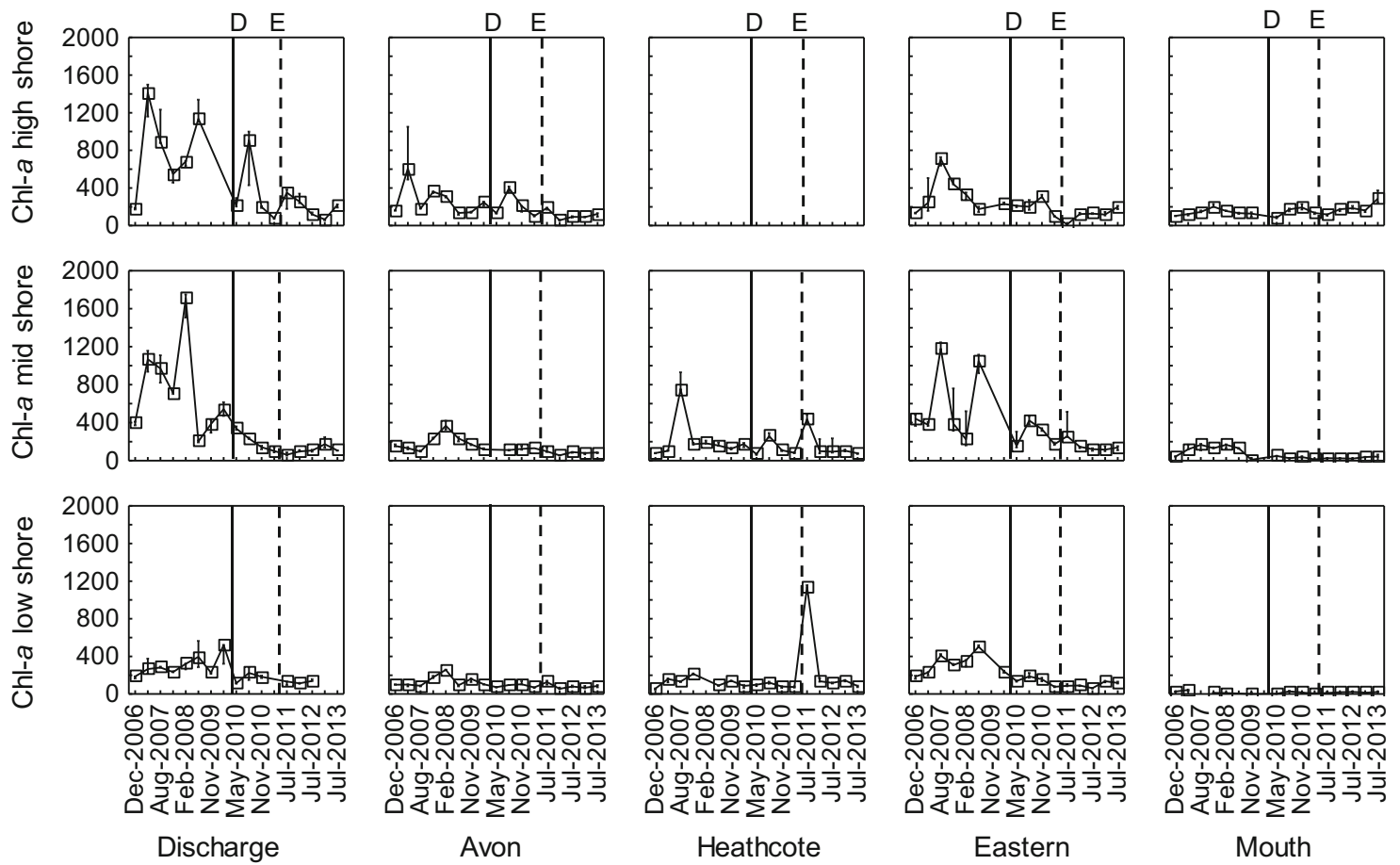

Fig. 6 Benthic microalgal (BMA) biomasses (mg chl- $a \mathrm{~m}^{-2}$ : medians and quartiles) at the five sites, 2006-2013. Times of March 2010 wastewater diversion (D) and February 2011 earthquake (E) are shown. For clarity,

\section{Water Column Properties}

The pre-diversion hypertrophic $\mathrm{NH}_{4}-\mathrm{N}$ concentrations of the AHE water column fell by $85-88 \%$ across the sites within $<$ 3-6 months following the wastewater diversion, indicating

Table 4 Benthic microalgae (BMA) biomasses (mg chl- $a \mathrm{~m}^{-2}$, medians) in AHE at the five study sites, at high, mid and low shore levels. Shown are pre-/post-wastewater diversion biomasses (in bold) and probabilities ( $p$ : Mann-Whitney $U$ ) that the pre- and post-diversion biomasses were from the same populations $(\leq 0.050$ italicized). There was no high shore level at Heathcote

\begin{tabular}{lll}
\hline Site & Shore level & BMA pre $/$ post \\
\hline Discharge & High & $\mathbf{8 1 8 / 1 9 7} p<0.001$ \\
& Mid & $\mathbf{5 9 7 / 1 1 6} p<0.001$ \\
& Low & $\mathbf{2 6 3 / 1 3 2} p<0.001$ \\
Avon & High & $\mathbf{2 0 8 / 1 1 5} p<0.001$ \\
& Mid & $\mathbf{1 6 8 / 9 2} p<0.001$ \\
\multirow{3}{*}{ Heathcote } & Low & $\mathbf{1 0 3 / 8 2} p<0.001$ \\
& Mid & $\mathbf{1 5 8 / 9 9} p=0.002$ \\
Eastern & Low & $\mathbf{1 1 8} / \mathbf{1 1 1} p=0.706$ \\
& High & $\mathbf{2 7 2 / 1 4 6} p<0.001$ \\
& Mid & $\mathbf{4 9 8 / 1 5 8} p<0.001$ \\
Mouth & Low & $\mathbf{2 9 9 / 1 1 7} p<0.001$ \\
& High & $\mathbf{1 3 7 / 1 6 2} p=0.098$ \\
& Mid & $\mathbf{1 2 0} / \mathbf{2 8} p<0.001$ \\
& Low & $\mathbf{1 2 / 1 6} p=0.153$ \\
\hline
\end{tabular}

a rapid improvement of water quality. However, changes in DIN concentration (sum of $\mathrm{NH}_{4}-\mathrm{N}$ and $\mathrm{NO}_{3}-\mathrm{N}$ ), estimated using the site averages were less than the predicted DIN load reduction for the estuary overall of $\sim 90 \%$, made using a budget of total river and small drain loads compared to wastewater loads (Burge 2007). This discrepancy was explicable in that the former estimate was influenced by data at Avon and Heathcote sites, and their relatively $\mathrm{NO}_{3}-\mathrm{N}$-rich adjacent rivers (Bolton-Ritchie and Main (2005). The post-diversion improvement of water quality was interrupted by wastewater

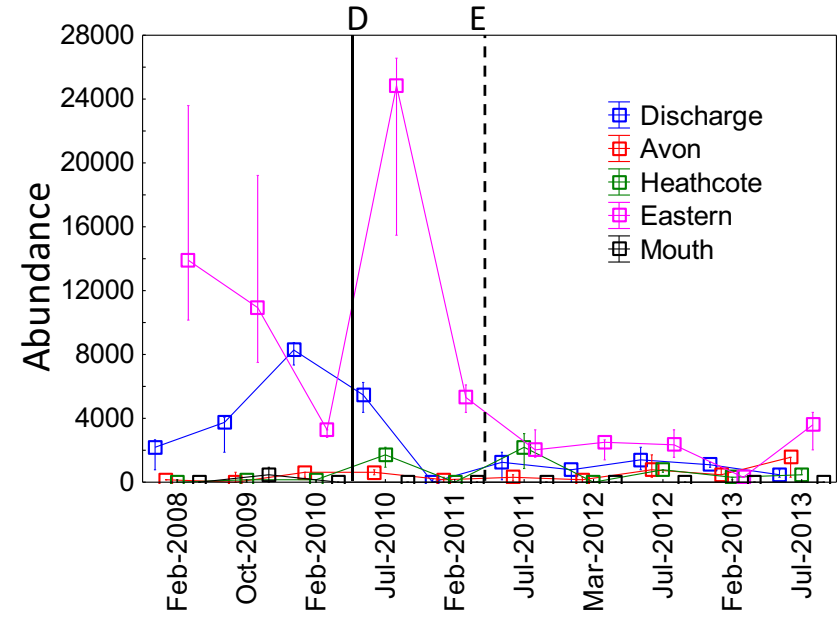

Fig. 7 Sedentary deposit-feeding polychaete abundances (numbers $\mathrm{m}^{-2}$ : medians and quartiles) at the five sites, 2008-2013. Times of March 2010 wastewater diversion (D) and February 2011 earthquake (E) are shown 
infrastructure breakdown from the earthquake, which caused sudden increases in $\mathrm{NH}_{4}-\mathrm{N}$, primarily at the river sites. However, these levels decreased again quickly (within $<3-$ 6 months) upon infrastructure repair, again indicating resilience in water quality state.

\section{Sediment and Porewater Properties}

Neither the wastewater diversion nor the earthquake had strong or persistent effects on sediment grain size, \%mud, $\% \mathrm{OM}, \% \mathrm{C}$ or $\% \mathrm{~N}$ at the sites. The time series of $\% \mathrm{OM}$ and porosity sampled from flux incubations were also stable, over a 6 -year period centred on the diversion. They were made over 0-60 $\mathrm{mm}$ from the sediment surface and were thus representative of a broad depth horizon of the surficial sediments. The only significant effects of the diversion on sediment properties were decreased $\% \mathrm{~N}$ and $-\delta^{15} \mathrm{~N}$ isotope ratio at Discharge, the site historically most impacted by wastewater. The $\% \mathrm{~N}$ decrease reflected the very large drops in $\mathrm{NH}_{4}-\mathrm{N}$ and organic matter loading upon diversion (Burge 2007). The lighter ${ }^{14} \mathrm{~N} /{ }^{15} \mathrm{~N}$ isotope ratio likely reflected decreased sediment denitrification at Discharge site, leaving more lighter ${ }^{14} \mathrm{~N}$ isotope in sediments. Also, diversion of partially denitrified wastewater from the Discharge site may have lightened ${ }^{14} \mathrm{~N} /{ }^{15} \mathrm{~N}$ ratio in the local water column (Barr et al. 2012) and lowered the Nisotope ratio of Discharge site sediments.

Samples taken in May 2011, 3 months after the February 2011 earthquake (Zeldis et al. 2011) showed elevated \%OM (1.7-2.7\%), indicating OM loading from the overflows of raw sewage caused by wastewater infrastructure breakdown. However, by August 2011 the overflows had been largely repaired and $\% \mathrm{OM}$ values at the study sites had returned to those sampled pre-earthquake (1.0-1.4\%). The earthquake also ejected liquefaction sediment mounds, which covered $34 \%$ of estuary surface at the Eastern site and 17-23\% at the other sites (Measures et al. 2011). The mound sediments were coarser than the surrounding original sediments (Zeldis et al. 2011): they had $80 \%$ of sediments $>125<500 \mu \mathrm{m}$ and $20 \%$ of sediments $<125 \mu \mathrm{m}$, while the original sediments had $55 \%$ of sediments $>125<500 \mu \mathrm{m}$ and $43 \%$ of sediments < $125 \mu \mathrm{m}$. The mounds also had lower $\% \mathrm{OM}, \% \mathrm{~N}$ and $\% \mathrm{C}$. The liquefaction was progressively re-distributed across the surrounding sediments, with the mounds disappearing completely by October 2013 (Bolton-Ritchie 2015). However, our sediment properties time-series showed this re-distribution had no significant long-term effect on grain size, $\% \mathrm{OM}, \% \mathrm{~N}$ and $\% \mathrm{C}$ in the original sediments. This was consistent with Bolton-Ritchie (2015) in the post-earthquake AHE for Plover St, Pleasant Pt and Humphreys Dr (Fig. 1), who showed only small earthquake-associated grain size changes over the long term.

The AHE values of \%OM (0.95-1.43), \%C (0.16-0.40) and $\% \mathrm{~N}(0.02-0.04)$ were low throughout their time series.
They can be compared with higher values in other NZ estuaries (\%C: 0.25-1.25; Robertson et al. (2015)), Californian estuaries (\%C: 0.1-9.5, \% N: 0.02-0.77; Sutula et al. (2014)) and Swedish estuaries (\%OM: 2.6-18; Engelsen et al. 2008). Other studies which sampled sediments in the AHE (Burge 2007; Bolton-Ritchie 2015; Robertson et al. 2015) also found low $\% \mathrm{OM}$ and $\% \mathrm{C}$ and $\% \mathrm{~N}$. The low $\mathrm{AHE} \% \mathrm{C}$ values were within the 'reference condition' ranges defined for healthy sediments in Californian lagoon-type estuaries by Sutula et al. (2014): $0.2-0.7 \%$, and by Pelletier et al. (2011): 0.2 $0.9 \%$ for eastern US estuaries. These $\% \mathrm{C}$ values were well below the 'enrichment thresholds' range of $1-1.5 \%$ defined by Sutula et al. (2014) to cause impairment of macrobenthic communities, and below the threshold defined for incipient macrobenthic impairment by Robertson et al. (2016) of $1.2 \%$, using a large dataset of NZ lagoon-type estuaries. AHE sediments were also sandy, with low proportions of mud, as shown by the broad-scale mapping by Rodrigo (1989), Robertson et al. (2002) (Fig. 1) and Robertson et al. (2015), who showed low $\%$ mud $(\sim 5-10 \%)$. The results were consistent with the low $\% \mathrm{OM}$ and $\% \mathrm{C}$ contents of other estuaries which have low mud content in NZ (Robertson et al. 2015), and elsewhere (Engelsen et al. 2008; Pelletier et al. 2011).

Pre-diversion porewater nutrient concentrations were high in AHE sediments $(\sim 100-340 \mu \mathrm{mol})$ - up to an order of magnitude higher than in oligotrophic Swedish sediments (Engelsen et al. 2008) but comparable to those measured by Robertson and Savage (2018) in another eutrophic NZ estuary (New River Estuary) and by Sakamaki et al. (2006) in a wastewater-affected Japanese estuary. Post-diversion, porewater $\mathrm{NH}_{4}-\mathrm{N}$ and $\mathrm{NO}_{3}-\mathrm{N}$ fell by $57 \%$ and $68 \%$ respectively, across the AHE sites. Considering this, the general lack of change in sediment solid-phase $\% \mathrm{~N}$ post-diversion was perhaps surprising. However, calculations made using sediment $\% \mathrm{~N}$, sediment $\%$ water and porewater DIN showed that porewater DIN was only a small percentage $(\leq 0.25 \%)$ of solid-phase $\mathrm{N}$ across the sites, pre- and post-diversion. This explains how porewater DIN concentrations could fall but leave the solid-phase $\% \mathrm{~N}$ values essentially unaffected. High porewater nutrient concentrations did not persist in the sandy AHE sediments, decreasing to much lower levels within $<1-$ 2 years, post-diversion. This was consistent with findings that retention of porewater nutrients depends on the sediment type concerned, with fine cohesive sediments retaining remineralised porewater nutrients more effectively than sandy sediments (Sakamaki et al. 2006; Engelsen et al. 2008; Huettel et al. 2014).

\section{Benthic Microalgae and Macrofauna}

The pre-diversion, dense mats of BMA in the AHE (up to $800 \mathrm{mg}$ chl- $a \mathrm{~m}^{-2}$ ), reflected the hypertrophic nutrient loading 
Table 5 Sediment $\mathrm{O}_{2}$ and nutrient fluxes $\left(\mu \mathrm{mol} \mathrm{m} \mathrm{m}^{-2} \mathrm{~h}^{-1}\right.$ : medians; positive values indicate fluxes out of sediment). For $\mathrm{O}_{2}$, shown are pre-/ post- wastewater diversion fluxes of (a) dark sediment $\mathrm{O}_{2}$ consumption (dark SOC: $\mathrm{O}_{2}$ flux in darkness) and (b) net primary production (NPP: $\mathrm{O}_{2}$ flux in light). For nutrients, shown pre-/post-diversion dark fluxes of (c) $\mathrm{NH}_{4}-\mathrm{N}$, (d) $\mathrm{NO}_{3}-\mathrm{N}$ and (e) DRP. $\mathrm{NH}_{4}-\mathrm{N}$ fluxes are compared between dark and light for (f) pre-diversion and (g) post-diversion periods. Gross $\mathrm{NH}_{4}-\mathrm{N}$ fluxes (differences of dark and light fluxes: medians) are given in (h). Denitrification (Denit) pre-/post-diversion fluxes are in (i). Also shown are probabilities ( $p$ : Mann-Whitney $U$ ) that the fluxes were from the same populations $(\leq 0.050$ italicized $)$

\begin{tabular}{|c|c|c|c|c|c|c|c|c|c|}
\hline Site & $\begin{array}{l}\text { (a) dark SOC, } \\
\text { pre/post }\end{array}$ & $\begin{array}{l}\text { (b) NPP, } \\
\text { pre/post }\end{array}$ & $\begin{array}{l}\text { (c) } \mathrm{NH}_{4}-\mathrm{N} \\
\text { dark, pre/post }\end{array}$ & $\begin{array}{l}\text { (d) } \mathrm{NO}_{3}-\mathrm{N} \\
\text { dark, pre/post }\end{array}$ & $\begin{array}{l}\text { (e) DRP } \\
\text { dark, pre/ } \\
\text { post }\end{array}$ & $\begin{array}{l}\text { (f) } \mathrm{NH}_{4}-\mathrm{N} \text { pre, } \\
\text { dark/light }\end{array}$ & $\begin{array}{l}\text { (g) } \mathrm{NH}_{4}-\mathrm{N} \\
\text { post, dark/light }\end{array}$ & $\begin{array}{l}\text { (h) } \mathrm{NH}_{4}-\mathrm{N} \\
\text { gross, pre/post }\end{array}$ & $\begin{array}{l}\text { (i) Denit } \\
\text { pre/post }\end{array}$ \\
\hline Discharge & $\begin{array}{l}-2458 /-1444 \\
p=0.050\end{array}$ & $\begin{array}{l}2384 /-218 \\
p<0.001\end{array}$ & $\begin{array}{l}301 / 165 \\
p=0.076\end{array}$ & & $\begin{array}{l}56 / 9 \\
p<0.001\end{array}$ & $\begin{array}{l}301 /-197 \\
p<0.001\end{array}$ & $\begin{array}{l}165 / 61 \\
p=0.005\end{array}$ & & $\begin{array}{l}89 / 51 \\
p<0.001\end{array}$ \\
\hline Avon & $\begin{array}{l}-981 /-813 \\
p=0.655\end{array}$ & $\begin{array}{l}-323 / 43 \\
p=0.060\end{array}$ & $\begin{array}{l}-57 / 25 \\
p=0.001\end{array}$ & $\begin{array}{l}24 /-6 \\
p<0.001\end{array}$ & $\begin{array}{l}1 / 4 \\
p=0.004\end{array}$ & $\begin{array}{l}-58 /-127 \\
p=0.004\end{array}$ & $\begin{array}{l}25 /-3 \\
p=0.016\end{array}$ & $\begin{array}{l}66 / 20 \\
p=0.026\end{array}$ & $\begin{array}{l}62 / 37 \\
p=0.004\end{array}$ \\
\hline Heathcote & $\begin{array}{l}-1194 /-1232 \\
p=0.875\end{array}$ & $\begin{array}{l}-229 / 139 \\
p=0.042\end{array}$ & $\begin{array}{l}143 / 54 \\
p=0.076\end{array}$ & $\begin{array}{l}24 /-33 \\
p<0.001\end{array}$ & $\begin{array}{l}5 / 8 \\
p=0.030\end{array}$ & $\begin{array}{l}143 / 12 \\
p<0.001\end{array}$ & $\begin{array}{l}54 / 25 \\
p=0.136\end{array}$ & $\begin{array}{l}121 / 16 \\
p<0.001\end{array}$ & $\begin{array}{l}45 / 51 \\
p=0.409\end{array}$ \\
\hline Eastern & $\begin{array}{l}-1224 /-1041 \\
p=0.107\end{array}$ & $\begin{array}{l}505 / 470 \\
p=0.840\end{array}$ & $\begin{array}{l}110 / 110 \\
p=0.509\end{array}$ & $\begin{array}{l}-4 /-17 \\
p<0.001\end{array}$ & $\begin{array}{l}10 / 6 \\
p=0.015\end{array}$ & $\begin{array}{l}110 / 49 \\
p=0.068\end{array}$ & $\begin{array}{l}110 / 55 \\
p=0.003\end{array}$ & $\begin{array}{l}39 / 70 \\
p=0.122\end{array}$ & $\begin{array}{l}56 / 34 \\
p=0.098\end{array}$ \\
\hline Mouth & $\begin{array}{l}-396 /-195 \\
p<0.001\end{array}$ & $\begin{array}{l}359 / 272 \\
p=0.015\end{array}$ & $\begin{array}{l}5 /-3 \\
p=0.029\end{array}$ & $\begin{array}{l}-6 /-5 \\
p=0.500\end{array}$ & $\begin{array}{l}1 / 1 \\
p=0.213\end{array}$ & $\begin{array}{l}5 / 0 \\
p=0.033\end{array}$ & $\begin{array}{l}-3 /-12 \\
p=<0.001\end{array}$ & $\begin{array}{l}19 / 6 \\
p=0.057\end{array}$ & $\begin{array}{l}39 / 14 \\
p=0.006\end{array}$ \\
\hline
\end{tabular}

the AHE was receiving. Their biomasses were comparable to maximum levels in the global tabulation by MacIntyre et al. (1996) and in estuaries with high wastewater loading (Peletier 1996; Essink 2003). Post-diversion, as nutrient concentrations fell in overlying water and porewater, BMA decreased within $<1-2$ years to $16-197 \mathrm{mg}$ chl- $a \mathrm{~m}^{-2}$, comparable to those in oligotrophic Swedish coastal waters (Engelsen et al. (2008): 28-149 mg chl- $a \mathrm{~m}^{-2}$ ) and among the lesser values tabulated by MacIntyre et al. (1996), Peletier (1996) and Essink (2003). BMA abundance thus responded quickly to decreases in water column and porewater nutrient pools (Cabrita and Brotas 2000; Lohrer et al. 2004), reaching levels similar to Manukau Harbour, a much less nutrient-rich NZ estuary (Cahoon and Safi 2002). BMA temporarily increased following the earthquake-driven sewage overflows at the Heathcote site (along with increased DIN in overlying water), but rapidly dissipated in the months following infrastructure repair, again showing a close relationship of BMA to dynamic dissolved nutrient pools.

The most abundant macrofauna found in the cores were sedentary deposit-feeding polychaetes, dominated by Aonides trifida at the sandier Eastern site and Capitellidae at the muddier, more eutrophic Discharge site. These spatial distributions were consistent with mud tolerances of these taxa in NZ estuaries (Robertson et al. 2015) with A. trifida favouring low \%mud $(<10 \%)$ and capitellids higher \%mud $(<40 \%)$. The high pre-diversion abundances of capitellids $(\sim 4000$ individuals $\mathrm{m}^{-2}$ ) at Discharge rivalled those in other eutrophic estuaries described by Pearson and Rosenberg (1978) and Cardoso et al. (2007). Cardoso et al. (2007) described the capitellids as fast growing, opportunistic and tolerant of degraded conditions, and showed their abundances to be diagnostic of changing eutrophication state. Although these taxa had contrasting habitat preferences, they both showed large and rapid abundance decreases (within $<1-2$ years) post-diversion, that accompanied falls in potential food sources, indexed by BMA (Peletier 1996). Other sites that supported less BMA showed much lower sedentary deposit-feeding polychaete abundances and negligible pre-/post-diversion differences.

\section{Oxygen, Nutrient and Denitrification Fluxes}

Apart from at the Discharge site, weak dynamics of sediment $\mathrm{O}_{2}$ fluxes were observed. To put these in context, Eyre and Ferguson (2009) gave a classification of trophic responses measured as SOC, with a eutrophic bench-mark reached at $4000 \mu \mathrm{mol} \mathrm{O} \mathrm{m}^{-2} \mathrm{~h}^{-1}$. Among the sites, only Discharge, the most heavily loaded site, reached this level (and only on occasion). Other AHE sites all had SOC rates < $2000 \mu \mathrm{mol} \mathrm{O} \mathrm{m}^{-2} \mathrm{~h}^{-1}$, similar to the lesser SOC rates compiled across many estuaries by Boynton and Kemp (2008) (their Fig. 18.16).

NPP also showed few strong or persistent responses to the wastewater diversion or earthquake. Strongest NPP responses to the diversion were at Discharge, with large falls in NPP coincident with large falls in BMA. The responses at Discharge were evident within $<1-2$ years post-diversion, similar to the rapid changes observed by Spivak (2015) when eutrophic sediment cores were transplanted to oligotrophic conditions. Rapid responses of NPP occurred at Avon and Heathcote sites in response to the riverine sewage overflows following the February 2011 earthquake, which corresponded to nutrient peaks in overlying water and BMA increases. These responses were transient however, disappearing by February 2012. At the Mouth site, $\mathrm{O}_{2}$ flux responses to the 

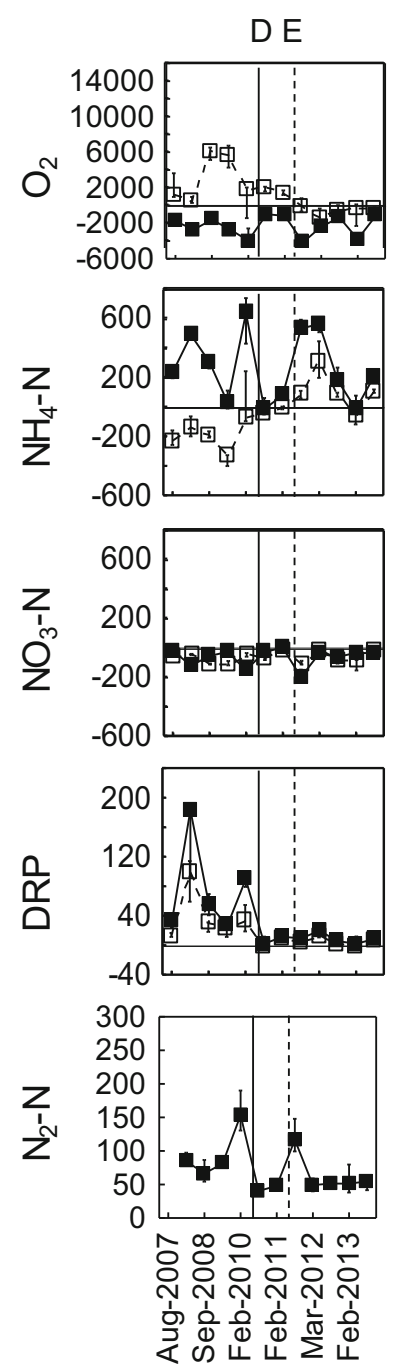

Discharge
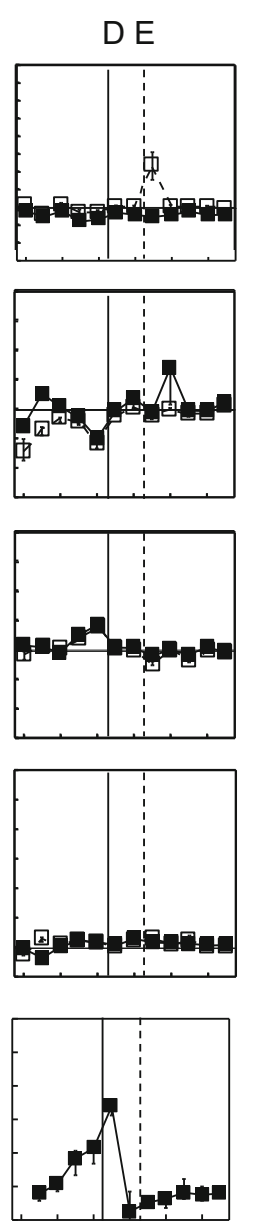

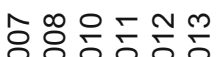

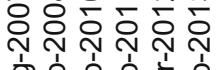

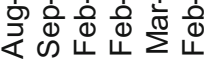

Avon
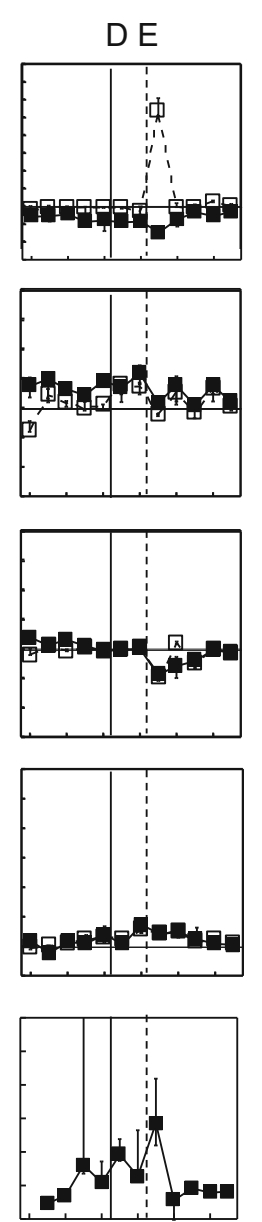

ㄴㅇㅇ은두는

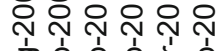

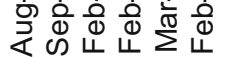

Heathcote
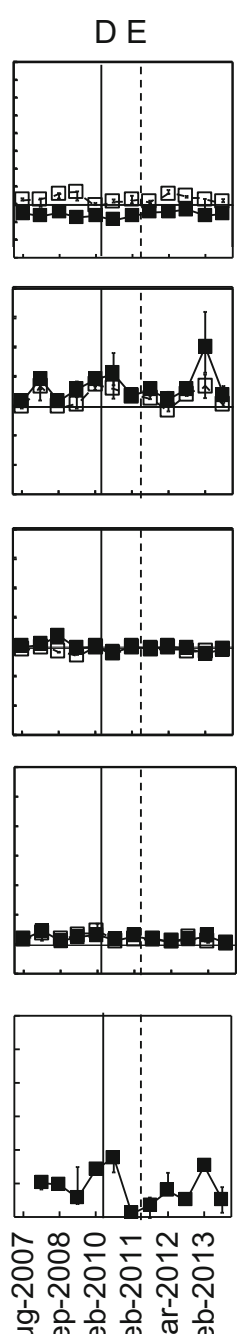

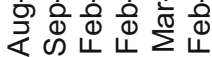

Eastern
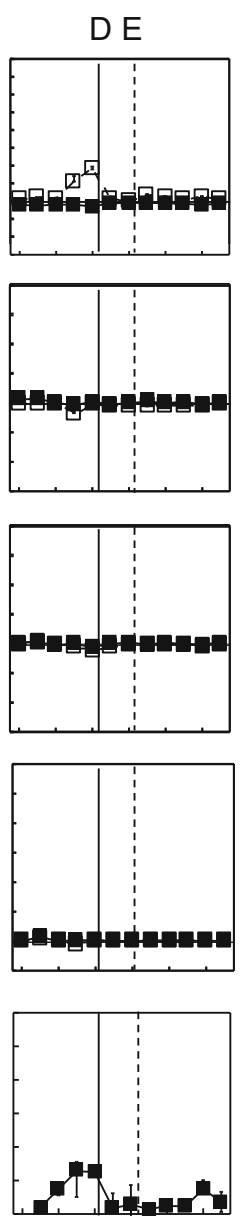

$\wedge \infty$ 은 $\mathrm{Nm}$

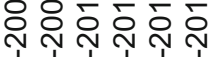

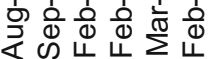

Mouth
Fig. 8 Oxygen, nutrient and denitrification fluxes $\left(\mu \mathrm{mol} \mathrm{m} \mathrm{m}^{-2} \mathrm{~h}^{-1}\right.$ : medians and quartiles) at the five study sites, 2007-2013. Closed squares are dark incubations and open squares are light incubations.
Positive values indicate fluxes out of sediment. Times of March 2010 wastewater diversion (D) and February 2011 earthquake (E) are shown. For clarity, only every second survey date is labelled

similar to BMA effects seen elsewhere (Tyler et al. 2003; Sundbäck et al. 2006; Cornwell et al. 2014). However, although BMA and nutrients in overlying water and porewater fell post-diversion, $\mathrm{NH}_{4}-\mathrm{N}$ flux rates, like $\mathrm{O}_{2}$ fluxes, showed inconsistent responses to the diversion. Potentially, this was due to counter-acting effects of reduced BMA post-diversion, which could enhance $\mathrm{NH}_{4}-\mathrm{N}$ efflux and reduce $\mathrm{O}_{2}$ efflux, and coincident reductions in organic inputs arising from wastewater, which could reduce $\mathrm{NH}_{4}-\mathrm{N}$ efflux and favour $\mathrm{O}_{2}$ efflux (Tyler et al. 2003). Macrobenthos changes may also have caused counter-acting effects at Discharge and Eastern sites, where BMA reductions may have allowed increased efflux of $\mathrm{NH}_{4}-\mathrm{N}$, while decreased abundance of sedentary deposit-feeding polychaetes may have reduced $\mathrm{NH}_{4}-\mathrm{N}$ efflux arising from their bio-irrigation and respiration (Lohrer et al. 2004; Engelsen et al. 2008). 
In contrast to $\mathrm{NH}_{4}-\mathrm{N}$ fluxes, $\mathrm{NO}_{3}-\mathrm{N}$ fluxes showed few differences between dark and light conditions, suggesting that BMA were utilizing $\mathrm{NH}_{4}-\mathrm{N}$ in preference to $\mathrm{NO}_{3}-\mathrm{N}$ (Cabrita and Brotas 2000; Lohrer et al. 2004). Because $\mathrm{NO}_{3}-\mathrm{N}$ fluxes were nearly always sinks irrespective of light conditions, they were likely driven most strongly by denitrification (Lohrer et al. 2004; Gongol and Savage 2016). This was consistent with Cabrita and Brotas (2000) who found that while $\mathrm{NO}_{3}-\mathrm{N}$ flux was controlled by the activity of denitrification, $\mathrm{NH}_{4}-\mathrm{N}$ flux was dependent on BMA biomass.

Our pre-diversion values of denitrification (39$89 \mu \mathrm{mol} \mathrm{N} \mathrm{m}^{-2} \mathrm{~h}^{-1}$ ) were similar to those of Gongol and Savage (2016) (their Fig. 4) who surveyed denitrification in the AHE pre-diversion using the paired-isotope technique. Our respective median values across the sites of 1.35 and $0.90 \mathrm{mmol} \mathrm{N}_{2} \mathrm{~m}^{-2} \mathrm{day}^{-1}$, pre- and post-diversion, were similar to the range determined by Cornwell et al. (2014) using MIMS in San Francisco Bay and lay within the range of 20 other coastal studies they listed, which were largely between 0 and $4 \mathrm{mmol} \mathrm{N}_{2} \mathrm{~m}^{-2}$ day $^{-1}$. The post-diversion reduction in AHE denitrification was consistent with loading rate-denitrification rate relationships seen in other studies (Cornwell et al. 1999; Cabrita and Brotas 2000; Gongol and Savage 2016) and occurred within $<1-2$ years. The coincidence of reduced denitrification with reduced porewater DIN was similar to Gongol and Savage (2016), who showed that coupled (sediment-driven) denitrification dominated direct (water column-driven) denitrification in the AHE.

Post-diversion, median gross $\mathrm{NH}_{4}-\mathrm{N}$ fluxes across the sites decreased by 3.3 -fold, but median denitrification fell only by 1.7-fold. This indicated that denitrification increased in efficiency in removing $\mathrm{NH}_{4}-\mathrm{N}$ from the system. Improved efficiency was also evident when comparing AHE system DIN loads, which decreased upon diversion from 63 to $7 \mathrm{mmol} \mathrm{N} \mathrm{m}^{-2}$ day $^{-1}$ (i.e. $90 \%$ ), with reductions in denitrification, which fell from 1.35 to $0.90 \mathrm{mmol} \mathrm{N}_{2} \mathrm{~m}^{-2}$ day $^{-1}$ (i.e. $50 \%$ ). Denitrification therefore increased substantially as a percentage of system DIN loading, from $\sim 5$ to $\sim 29 \%$ (a factor of 2 was used to convert values of denitrified $\mathrm{N}_{2}$ to molar $\mathrm{N}$ in this calculation). The percentage of the load which was denitrified post-diversion was consistent with that seen in other non-eutrophic estuaries of $\sim 15-20 \%$ (Seitzinger 1988; Fulweiler and Nixon 2012; Cornwell et al. 2014) and indicated that AHE system resilience was considerably improved post-diversion, in terms of its ability to accommodate its DIN loading via denitrification.

\section{Role of Sediments in AHE Trophic Status}

Estuarine eutrophication (expressed as increased primary production) could be expected to result in the accumulation of $\mathrm{OM}$ in sediments. For example, it is common in depositional estuaries for sediments to contain upwards of 1-10\%
(Valdemarsen et al. 2014). Our results for the AHE, however, showed \%C never exceeding $0.4 \%$. A review of sediment accumulation rate (SAR) in the AHE since 1975 (Burge 2007) showed that its average SAR was low, less than $1 \mathrm{~mm}$ year $^{-1}$, in contrast with much higher rates in other NZ estuaries of $1-33 \mathrm{~mm}$ year $^{-1}$ (Morrison et al. 2009). This indicates a balance between the import and export of particulate material in the AHE, consistent with its comparatively low $\% \mathrm{C}$ in its sediments. It appears that $\mathrm{OM}$ loaded from the wastewater discharge and from the primary production resulting from nutrient loading (BMA, macroalgal biomass) has been quickly mineralised and exported, such that there has been little OM accumulation in the AHE. The AHE sediments had low \%OM values both before and after the diversion, i.e. they never harboured substantial amounts of stored OM, which otherwise could have driven large $\mathrm{O}_{2}$ and nutrient fluxes commonly associated with eutrophic sediments. This accounted for the generally weak $\mathrm{O}_{2}$ and nutrient flux responses to the diversion and earthquake, except at the most eutrophic site, Discharge.

These results are explicable in that AHE sediments are coarse and likely to be well irrigated, compared to less permeable, muddy sediments (Huettel and Rusch 2000) which typically harbour higher $\% \mathrm{OM}$, solid phase $\% \mathrm{~N}$ and $\% \mathrm{C}$ (Engelsen et al. 2008). The results are consistent with Valdemarsen et al. (2014), Borja et al. (2010) and Huettel and Rusch (2000) who described this behaviour for sandy, high energy systems. The $\mathrm{N}$ loading the AHE received prior to the diversion was in dissolved inorganic form $\left(\mathrm{NH}_{4}-\mathrm{N}\right.$ predominately) while its allochthonous organic loading was dominated by labile freshwater phytoplankton from the wastewater oxidation ponds (Burge 2007). Upon entering the estuary, this loading was either flushed rapidly from the estuary or, if deposited to the estuary bed, rapidly oxidized in the coarse, well-flushed surficial sediments. Similarly, autochthonous organic loading contributed by high biomasses of senescent macroalgae and BMA appears to have been readily oxidized and exported from the system, rather than stored.

Because delivery of OM to the sediments has not exceeded AHE mineralisation capacity, there has been limited scope for the sediments to exert any strong 'legacy' effects, with respect to nutrient release/recycling post-wastewater diversion. This was reflected in the rapid decreases in water column and porewater nutrients commensurate with the diversion, and the evanescent responses of water column nutrients, BMA and NPP to subsequent earthquake-driven enrichment. With the diversion, BMA and enrichment-associated polychaetes decreased, and denitrification efficiency increased. The results contrast with the long legacy of effects seen in the low energy, muddy subtidal zone of the Nervión River Estuary of Borja et al. (2010) and a number of other subtidal systems they describe. The findings thus supported the study hypothesis that following the wastewater diversion, the sandy, 
well-flushed AHE sediments would not harbour a long legacy of eutrophication, and that water quality of both the water column and porewater would rapidly improve, along with other indicators of ecological health.

This study sampled five widely-distributed sites in the AHE that represented a range of its physiographic features (both river mouths, inner and outer estuary, muddy sand to coarse sand, high to low eutrophication). Regardless, scaling its findings estuary-wide could be challenging. Other AHE studies help generalise its results, including the spatially-extensive sediment surveys of Rodrigo (1989) and Robertson et al. (2002) (Fig. 1). Bolton-Ritchie (2015) sampled sites in the inner and outer estuary (at Pleasant Point, Plover and Discharge sites: Fig. 1) between 2008 and 2013. Like the present study, she showed large sediment grain sizes and low \%OM, and large BMA decreases pre- to post-diversion. Also, in common was a postearthquake increase in \%OM and BMA at inner-estuary Humphreys Drive (near the Heathcote site).

The earthquake changed the estuary bed height (Measures et al. 2011), affecting tidal inundation profiles and potentially affecting consistency of the time series. Height changes were small at Discharge $(+4 \mathrm{~cm})$, Eastern $(-4 \mathrm{~cm})$ and Mouth (+ $1 \mathrm{~cm}$ ), relative to the mean tidal range of the AHE of $2 \mathrm{~m}$. Avon and Heathcote sites changed more $(-22 \mathrm{~cm}$ and + $25 \mathrm{~cm}$, respectively) or $\sim 10-13 \%$ of the tidal range. Yet, their responses were like the other sites (little change in bulk properties, reduced water column nutrients, porewater nutrients, BMA and gross $\mathrm{NH}_{4}-\mathrm{N}$ fluxes), indicating that their responses were driven primarily by the diversion rather than by changed inundation.

The continuing nutrient loading from the AHE's rivers has an evident ongoing effect on AHE water quality, albeit at a much lower level than pre-diversion (Bolton-Ritchie 2014). This has continued to affect the trajectory of change in AHE macroalgal biochemistry (Barr et al. 2012) but at a much reduced level of macroalgal areal cover (Barr et al. (2019): NIWA, personal communication). Significantly, recent surveys of seagrass (Zostera muelleri) in the AHE (Gibson and Marsden 2016) have shown an expansion of seagrass beds of $40 \%$, over a four-year period post-diversion (2015 census) as seen in other estuaries recovering from eutrophication (e.g. Cardoso et al. (2007)). Along with the general improvement in water quality, these outcomes indicate the estuary-wide improvement in AHE health resulting from the wastewater diversion.

\section{Conclusion}

The AHE has responded well, in terms of improved trophic condition, to the 2010 commissioning of the ocean outfall which was an expensive infrastructural upgrade (\$NZ $80 \mathrm{M})$ for Christchurch. Furthermore, the 2011 Christchurch earthquake was shown to have caused only temporary interruption to the trajectory of trophic improvement in the estuary. Upon repair of the wastewater infrastructure, trophic indices were shown to improve again quickly. The time frame for recovery of eutrophic estuaries is of high interest to stakeholders including regulators and the public involved in remediation efforts. This study informs this issue and is particularly relevant because this estuary type, well-flushed tidal lagoon (Hume et al. 2007, 2016), is a common one in NZ (Plew et al. 2018). It is also common among NZ estuaries in having a sandy sediment, with low \%OM (Robertson et al. (2015). Several of these estuaries are currently receiving heavy diffuse-source catchment loading of nutrients and are eutrophic (Plew et al. 2018; Robertson and Savage 2018). The present study has shown that this common estuary type is sensitive to eutrophication via water column forcing but is also amenable to remediation, suggesting that such estuaries could respond similarly to the AHE, if water quality of their loading was improved. The results were consistent with conclusions of Borja et al. (2010) for coarse-sediment, high energy systems internationally, albeit unusual in providing longterm monitoring data showing biological elements together with physicochemical data from waters and sediments that show the recovery trajectories. We demonstrate that this common estuary type (sandy, well-flushed tidal lagoon) may be resilient to eutrophication upon stressor removal.

Acknowledgements Thanks to Mireille Consalvey and Laura Drummond (NIWA) for field assistance, Mike Bourke (Christchurch City Council) for CWTP wastewater flow data and Lesley BoltonRitchie (Environment Canterbury) for estuary water quality data.

Funding Information This work was supported primarily by New Zealand Ministry for Business, Innovation and Employment contract number UOCX0902 and partially by NIWA SSIF contract number FWWQ1812.

Open Access This article is licensed under a Creative Commons Attribution 4.0 International License, which permits use, sharing, adaptation, distribution and reproduction in any medium or format, as long as you give appropriate credit to the original author(s) and the source, provide a link to the Creative Commons licence, and indicate if changes were made. The images or other third party material in this article are included in the article's Creative Commons licence, unless indicated otherwise in a credit line to the material. If material is not included in the article's Creative Commons licence and your intended use is not permitted by statutory regulation or exceeds the permitted use, you will need to obtain permission directly from the copyright holder. To view a copy of this licence, visit http://creativecommons.org/licenses/by/4.0/.

\section{References}

Barr, N., J.R. Zeldis, C. Gongol, L. Drummond, and K. Scheuer. 2012. Effects of the Canterbury earthquakes on Avon-Heathcote Estuary / Ihutai macroalgae. Technical Report Investigations and Monitoring Group R12/91: 33. 2012. Environment Canterbury. 
Barr N., J. Zeldis, K. Scheuer, and D. Schiel (2019) Macroalgal Bioindicators of Recovery from Eutrophication in a Tidal Lagoon Following Wastewater Diversion and Earthquake Disturbance. Estuaries and Coasts. https://doi.org/10.1007/s12237-019-00654-7.

Bolton-Ritchie, L. 2014. Water quality within the estuary of the Heathcote and Avon Rivers/Ihutai. 2007-2013. Environment Canterbury Technical Report R14/112.

Bolton-Ritchie, L. 2015. The sediments and biota within the estuary of the Heathcote and Avon Rivers/Ihutai 2007-2013. Environment Canterbury Technical Report R15/46: 102 pp.

Bolton-Ritchie, L., and M. Main. 2005. Nutrient water quality AvonHeathcote estuary/Ihutai: Inputs, concentrations and potential effects. Environment Canterbury Technical Report U05/71: 84 pp.

Borja, Á., D. Dauer, M. Elliott, and C. Simenstad. 2010. Medium- and long-term recovery of estuarine and coastal ecosystems: Patterns, rates and restoration effectiveness. Estuaries and Coasts 33 (6): $1249-1260$.

Boynton, W., and W. Kemp. 2008. Estuaries. In Nitrogen in the marine environment, ed. D. Capone, D. Bronk, M. Mulholland, and E. Carpenter, 809-856. Burlington: Elsevier.

Burge, P.I. 2007. Sedimentation in the Avon-Heathcote estuary/Ihutai An analysis of past and present studies: $49 \mathrm{pp}$. https://drive.google. com/file/d/0B43syqhCcNE_ZTUyMGVhNGMtZjEzZC 00MjE4LTg0N2QtZmY3NDdiOGRlYjk2/view?num=50\&sort= name\&layout=list\&pli=1. Accessed October 2019.

Cabrita, M.T., and V. Brotas. 2000. Seasonal variation in denitrification and dissolved nitrogen fluxes in intertidal sediments of the Tagus estuary, Portugal. Marine Ecology Progress Series 202: 51-65.

Cahoon, L.B., and K.A. Safi. 2002. Distribution and biomass of benthic microalgae in Manukau harbour, New Zealand. New Zealand Journal of Marine and Freshwater Research 36 (2): 257-266.

Cardoso, P.G., M. Bankovic, D. Raffaelli, and M.A. Pardal. 2007. Polychaete assemblages as indicators of habitat recovery in a temperate estuary under eutrophication. Estuarine, Coastal and Shelf Science 71 (1-2): 301-308.

Cornwell, J., W. Kemp, and T. Kana. 1999. Denitrification in coastal ecosystems: Methods, environmental controls, and ecosystem level controls, a review. Aquatic Ecology 33 (1): 41-54.

Cornwell, J., P. Glibert, and M. Owens. 2014. Nutrient fluxes from sediments in the San Francisco Bay Delta. Estuaries and Coasts 37 (5): $1120-1133$

Diaz, R.J., D.C. Rhoads, J.A. Blake, R.K. Kropp, and K.E. Keay. 2008. Long-term trends of benthic habitats related to reduction in wastewater discharge to Boston Harbor. Estuaries and Coasts 31 (6): 1184-1197.

Engelsen, A., S. Hulth, L. Pihl, and K. Sundbäck. 2008. Benthic trophic status and nutrient fluxes in shallow-water sediments. Estuarine, Coastal and Shelf Science 78 (4): 783-795.

Essink, K. 2003. Response of an estuarine ecosystem to reduced organic waste discharge. Aquatic Ecology 37 (1): 65-76.

Eyre, B., and A.P. Ferguson. 2009. Denitrification efficiency for defining critical loads of carbon in shallow coastal ecosystems. Hydrobiologia 629 (1): 137-146.

Eyre, B.D., S. Rysgaard, T. Dalsgaard, and P.B. Christensen. 2002. Comparison of isotope pairing and $\mathrm{N}_{2}$ :Ar methods for measuring sediment denitrification-Assumption, modifications, and implications. Estuaries 25 (6): 1077-1087.

Ford, R.B., and C. Honeywill. 2002. Grazing on intertidal microphytobenthos by macrofauna: Is pheophorbide a a useful marker? Marine Ecology Progress Series 229: 33-42.

Fulweiler, R., and S. Nixon. 2012. Net sediment $\mathrm{N}_{2}$ fluxes in a southern New England estuary: Variations in space and time. Biogeochemistry 111 (1-3): 111-124.

Gibson, K., and I.D. Marsden. 2016. Seagrass Zostera muelleri in the Avon-Heathcote Estuary/Ihutai, summer 2015-2016. In Estuarine Research Report: 40 pp. Christchurch: University of Canterbury.
Gongol, C., and C. Savage. 2016. Spatial variation in rates of benthic denitrification and environmental controls in four New Zealand estuaries. Marine Ecology Progress Series 556: 59-77.

Hu, W.F., W. Lo, H. Chua, S.N. Sin, and P.H.F. Yu. 2001. Nutrient release and sediment oxygen demand in a eutrophic land-locked embayment in Hong Kong. Environment International 26 (5-6): 369-375.

Huettel, M., and A. Rusch. 2000. Advective particle transport into permeable sediments-Evidence from experiments in an intertidal sandflat. Limnology and Oceanography 45 (3): 525-533.

Huettel, M., P. Berg, and J.E. Kostka. 2014. Benthic exchange and biogeochemical cycling in permeable sediments. Annual Review Marine Science 6 (1): 23-51.

Hume, T., T. Snelder, M. Weatherhead, and R. Liefting. 2007. A controlling factor approach to estuary classification. Journal of Ocean and Coastal Management 50 (11-12): 905-929.

Hume, T., P. Gerbeaux, D. Hart, H. Kettles, and D. Neale. 2016. A classification of New Zealand's coastal hydrosystems. NIWA Client Report HAM2016-062: 120 pp.

Jeffrey, S., and G. Humphrey. 1975. New spectrophotometric equations for determining chlorophylls $a, b, c 1$ and $c 2$ in higher plants, algae, and natural phytoplankton. Biochemie und Physiologie der Pflanzen 167 (2): 191-194.

Jones, H.P., and O.J. Schmitz. 2009. Rapid recovery of damaged ecosystems. PLoS One 4: e5653.

Kana, T., and D. Weiss. 2004. Comment on "Comparison of Isotope Pairing and $\mathrm{N}_{2}$ : Ar Methods for Measuring Sediment Denitrification" by B. D. Eyre, S. Rysgaard, T. Dalsgaard, and P. Bondo Christensen. 2002. "Estuaries" 25:1077-1087. Estuaries and Coasts 27: 173-176.

Kana, T., C. Darkangelo, M. Hunt, J. Oldham, G. Bennett, and J. Cornwell. 1994. Membrane inlet mass spectrometer for rapid highprecision determination of $\mathrm{N}_{2}, \mathrm{O}_{2}$, and $\mathrm{Ar}$ in environmental water samples. Analytical Chemistry 66 (23): 4166-4170.

Lachat. 2010. Methods list for automated ion analyzers http://www. lachatinstruments.com/download/LL022-Methods-List_5-10. pdf1125. Accessed October 2019.

Lohrer, A., S. Thrush, and M. Gibbs. 2004. Bioturbators enhance ecosystem function through complex biogeochemical interactions. Nature 431 (7012): 1092-1095.

MacIntyre, H.L., R.J. Geider, and D.C. Miller. 1996. Microphytobenthos: The ecological role of the "secret garden" of unvegetated, shallowwater marine habitats. I. Distribution, abundance and primary production. Estuaries 19 (2): 186-201.

Measures, R., M. Hicks, U. Shankar, J. Bind, J. Arnold, and J. Zeldis. 2011. Mapping earthquake induced topographic change and liquefaction in the Avon-Heathcote Estuary. NIWA Client Report CHC2011-066: 28 pp.

Morrison, M., M. Lowe, D. Parsons, N. Usmar, and I. McLeod. 2009. A review of land-based effects on coastal fisheries and supporting biodiversity in New Zealand. In New Zealand Aquatic Environment and Biodiversity Report 37: 100 pp. Wellington: New Zealand Ministry of Fisheries.

NRC. 2000. Clean coastal waters understanding and reducing the effects of nutrient pollution. Washington DC: National Academy Press 405 pp.

Pearson, T.H., and R. Rosenberg. 1978. Macrobenthos succession in relation to organic enrichment and pollution of the marine environment. Oceanography and Marine Biology: An Annual Review 16: 229-311.

Peletier, H. 1996. Long-term changes in intertidal estuarine diatom assemblages related to reduced input of organic waste. Marine Ecology Progress Series 137: 265-271.

Pelletier, M.C., D.E. Campbell, K.T. Ho, R.M. Burgess, C.T. Audette, and N.E. Detenbeck. 2011. Can sediment total organic carbon and grain size be used to diagnose organic enrichment in estuaries? Environmental Toxicology and Chemistry 30 (3): 538-547. 
Plew, D.R., J.R. Zeldis, U. Shankar, and A.H. Elliott. 2018. Using simple dilution models to predict New Zealand estuarine water quality. Estuaries and Coasts 41 (6): 1643-1659.

Robertson, B., and C. Savage. 2018. Mud-entrained macroalgae utilise porewater and overlying water column nutrients to grow in a eutrophic intertidal estuary. Biogeochemistry 139 (1): 53-68.

Robertson, B., P. Gillespie, R. Asher, S. Frisk, N. Keeley, G. Hopkins, S.J. Thompson, and B.J. Tuckey. 2002. Estuarine Environmental Assessment and Monitoring, A National Protocol. Part A. Development, Part B. Appendices and Part C. Application. Sustainable Management Fund Contract No.5096. Part A. 93p. Part B. 159p. Part C 40p plus field sheets.

Robertson, B.P., J.P.A. Gardner, and C. Savage. 2015. Macrobenthicmud relations strengthen the foundation for benthic index development: A case study from shallow, temperate New Zealand estuaries. Ecological Indicators 58: 161-174.

Robertson, B.P., C. Savage, J.P.A. Gardner, B.M. Robertson, and L.M. Stevens. 2016. Optimising a widely-used coastal health index through quantitative ecological group classifications and associated thresholds. Ecological Indicators 69: 595-605.

Rodrigo, A.G. 1989. Surficial sediment-heavy metal associations in the Avon-Heathcote estuary, New Zealand. New Zealand Journal of Marine and Freshwater Research 23 (2): 255-262.

Sakamaki, T., O. Nishimura, and R. Sudo. 2006. Tidal time-scale variation in nutrient flux across the sediment-water interface of an estuarine tidal flat. Estuarine, Coastal and Shelf Science 67 (4): 653663.

Seitzinger, S. 1988. Denitrification in freshwater and coastal marine ecosystems: Ecological and geochemical significance. Limnology and Oceanography 33: 702-724.

Smith, S., W. Kimmerer, E. Laws, R. Brock, and T. Walsh. 1981. Kaneohe Bay sewage diversion experiment: Perspectives on ecosystem responses to nutrient perturbation. Pacific Science 35: 279-395.
Smith, V., G. Tilman, and J. Nekola. 1999. Eutrophication: Impacts of excess nutrient inputs on freshwater, marine, and terrestrial ecosystems. Environmental Pollution 100 (1-3): 179-196.

Spivak, A.C. 2015. Benthic biogeochemical responses to changing estuary trophic state and nutrient availability: A paired field and mesocosm experiment approach. Limnology and Oceanography 60 (1): 3-21.

Sundbäck, K., A. Miles, and F. Linares. 2006. Nitrogen dynamics in nontidal littoral sediments: Role of microphytobenthos and denitrification. Estuaries and Coasts 29 (6): 1196-1211.

Sutula, M., L. Green, G. Cicchetti, N. Detenbeck, and P. Fong. 2014. Thresholds of adverse effects of macroalgal abundance and sediment organic matter on benthic habitat quality in estuarine intertidal flats. Estuaries and Coasts 37 (6): 1532-1548.

Taylor, D.I., C.A. Oviatt, and D.G. Borkman. 2011. Non-linear responses of a coastal aquatic ecosystem to large decreases in nutrient and organic loadings. Estuaries and Coasts 34 (4): 745-757.

Tyler, A.C., K.J. McGlathery, and I.C. Anderson. 2003. Benthic algae control sediment-Water column fluxes of organic and inorganic nitrogen compounds in a temperate lagoon. Limnology and Oceanography 48 (6): 2125-2137.

Valdemarsen, T., C.O. Quintana, E. Kristensen, and M.R. Flindt. 2014. Recovery of organic-enriched sediments through microbial degradation: Implications for eutrophic estuaries. Marine Ecology Progress Series 503: 41-58.

Vopel, K., P.S. Wilson, and J. Zeldis. 2012. Sediment-seawater solute flux in a polluted New Zealand estuary. Marine Pollution Bulletin 64 (12): 2885-2891.

Zeldis, J., J. Skilton, P. South, and D. Schiel. 2011. Effects of the Canterbury earthquakes on Avon-Heathcote Estuary / Ihutai Ecology. NIWA Client Report CHC2011-101: 27 pp. 